\title{
Performance of cumulus parameterization schemes in the simulation of Indian Summer Monsoon using RegCM4
}

\author{
S. MAITY ${ }^{1 *}$, M. MANDAL ${ }^{1}$, S. NAYAK ${ }^{2}$ and R. BHATLA ${ }^{3}$ \\ ${ }^{1}$ Centre for Oceans, Rivers, Atmosphere and Land Sciences (CORAL), Indian Institute of Technology, Kharagpur, \\ Kharagpur-721302, India \\ ${ }^{2}$ National Research Institute for Earth Science and Disaster Resilience, Department of Integrated Research on Disaster \\ Risk Reduction, Division Tennodai, Tsukuba-shi Ibaraki, 305-0006, Japan \\ ${ }^{3}$ Department of Geophysics, Banaras Hindu University, Varanasi - 221 005, Uttar Pradesh, India \\ *Corresponding author; email: suman.buie@gmail.com
}

Received: September 2, 2016; accepted: May 31, 2017

\begin{abstract}
RESUMEN
El monzón de verano de la India (MVI) se origina a partir de una convección de gran escala, por lo que su simulación debe basarse en la representación adecuada de la convección de cumulus en el modelo. En este estudio se analiza el desempeño de diversos esquemas de parametrización en simulaciones del MVI. El modelo climático regional RegCM4 se acopla con el modelo de suelo CLM 3.5 con una resolución de 30 $\mathrm{km}$ para simular el MVI en el periodo comprendido entre el 1 de mayo y el 30 de septiembre en tres años consecutivos: 2007, 2008 y 2009. Se llevaron a cabo cinco experimentos numéricos con cinco esquemas de convección (Kuo, Grell, MIT, GO_ML [MIT sobre tierra y Grell sobre el océano] y GL_MO [Grell sobre tierra y MIT sobre el océano]) para cada uno de los años mencionados. Algunas características importantes del MVI simulado con el modelo, a saber la corriente en chorro del oeste de niveles bajos, la corriente en chorro del este de niveles altos, los sistemas de baja presión superficial y los de alta presión sobre la meseta tibetana, etc., se analizan y comparan con datos de reanálisis del National Center for Environmental Prediction (NCEP). Se encontró que el modelo con el esquema de convección MIT simula mejor los sistemas de baja presión superficial asociados con alta temperatura en el noroeste de la India y Paquistán durante los tres años, en tanto que el esquema GL_MO simula mejor la distribución espacial y exactitud de la temperatura. El modelo con el esquema de convección MIT reproduce adecuadamente la corriente en chorro del oeste de niveles bajos con fuerza algo menor que el reanálisis del NCEP. Todos los esquemas simularon aceptablemente la ubicación y fuerza de la corriente en chorro tropical del este, con cierta incertidumbre en cuanto a la fuerza, y mayor exactitud con el esquema MIT. La comparación entre la precipitación simulada y las bases de datos de la Unidad de Investigación del Clima con resolución de $0.5^{\circ}$ (CRU TS3.22) indica que la precipitación media estacional y mensual se simula mejor con los esquemas de convección MIT y GO_ML. Sin embargo, todos los esquemas de convección del modelo subestiman de manera significativa estas mismas variables sobre el centro y el oeste de la India. Un flujo mayor de calor sensible y un flujo menor de calor latente afectan de manera significativa la simulación de temperatura superficial y precipitación con todos los esquemas. El análisis estadístico indica que los esquemas GL_MO y GO_ML del modelo reproducen de manera adecuada la temperatura superficial y la cantidad de precipitación, pero el esquema MIT simula mejor la circulación. Aunque este último implica una desviación ligeramente mayor a la de los dos esquemas combinados, se observó que la distribución espacial y otras características sinópticas de la temperatura superficial y la precipitación durante el MVI fueron bien simuladas por el esquema MIT. En conclusión, tomando en cuenta el desempeño de todos los esquemas, el modelo RegCM4 con el esquema MIT de convección de cumulus ofrece una mejor simulación de las características estacionales y mensuales del MVI.
\end{abstract}




\section{ABSTRACT}

The Indian Summer Monsoon (ISM) is driven by organized large-scale convection; hence, its simulation is expected to depend on an appropriate representation of cumulus convection in the model. In the present study, the performance of different cumulus parameterization schemes is examined towards simulations of the ISM. The Regional Climate Model (RegCM4) is coupled with the Community Land Model (CLM 3.5) at $30 \mathrm{~km}$ resolution for the period May 1-September 30 for seasonal simulation of the ISM in three consecutive years, 2007, 2008, and 2009. Five numerical experiments with five convection schemes (Kuo, Grell, MIT, GO_ML [Grell over ocean and MIT over land], GL_MO [Grell over land and MIT over ocean]) are conducted for each of these three years. Some important features of the ISM simulated by the model, viz. low level westerly jet, upper level easterly jet, heat low, Tibetan high, etc., are analyzed and compared with that of the National Center for Environmental Prediction (NCEP) reanalysis. We found that the heat low over northwest India and Pakistan in all the three years is better simulated by the model with the MIT convection scheme compared to other convection schemes, whereas spatial distribution and accuracy of surface temperature is better simulated using GL_MO rather than MIT. The low level westerly jet is well captured by the model with MIT with slightly weaker strength compared to the National Center for Environmental Prediction (NCEP) reanalysis. The location and strength of the tropical easterly jet is well predicted in each simulation with some uncertainty in strength, and are better simulated with MIT. The comparison of the model simulated rainfall with $0.5^{\circ} \times 0.5^{\circ}$ datasets from the Climate Research Unit (CRU TS3.22) indicates that seasonal and monthly average rainfall are well simulated with MIT and GO_ML; however, the same over central and western India is significantly underestimated by the model with all the convection schemes. Comparatively, higher sensible heat flux and lower latent heat flux are noticed in the model simulation with all schemes. This change of fluxes affects surface temperature and rainfall simulation significantly. The statistical analysis indicates that surface temperature and rainfall are well reproduced by the model with GL_MO and GO_ML, but circulation is better simulated with MIT only. It is observed that although the bias in the model with MIT is slightly higher than that of the two mixed schemes, the spatial distribution and other synoptic features of surface temperature and rainfall during ISM are well simulated. Thus, considering overall performances, the RegCM4 with MIT the cumulus convection scheme provides better simulation of seasonal and monthly features of the monsoon.

Keywords: Indian summer monsoon, seasonal simulation, cumulus convection.

\section{Introduction}

The Indian Summer Monsoon (ISM), which is characterized by seasonal reversal of trade winds from northeast to southwest due to differential heating of the Indian landmass and neighboring oceans, is a major component of the tropical circulation. It contributes to more than $70 \%$ of the annual rainfall over India (Parthasarathy et al., 1994). Due to its large impact on Indian economy, the ISM has been an important topic of research for more than a century now. Numerous studies have been conducted to understand the mechanism and physical processes (i.e., large scale circulation processes) of the ISM (Shukla and Paolino, 1983; Shukla and Fennessy, 1994; Bhaskaran et al., 1996; Goswami et al., 1998; Webster et al., 1998; Lal et al., 2000; Zhou and Li, 2002; Mohanty et al., 2002, 2005; Kang et al., 2002; Rao et al., 2004; Singh et al., 2007; Raju et al., 2010; Zou and Zhou, 2013, 2014; Zhu, 2015; Almazroui et al., 2016). However, convection plays an important role in the development and maintenance of the ISM through the release of latent heat and vertical transport of heat, moisture and momentum (Ghosh et al., 1978; Kain, 1993; Zhu, 2015). A number of schemes have been developed over the years to parameterize the cumulus convection in large-scale numerical models, but none of the studies show a universal conceptual framework to parameterize convection. Thus, it is important to undertake a sensitivity study to have a suitable choice of convection scheme for a particular region.

A comparative study of different Kuo type of cumulus convection schemes (CCS) (Kuo, 1965, 1974) during different epochs (pre-onset, onset and break) of the Asian Summer Monsoon was conducted by Das et al. (1988), who inferred that the Kuo-Anthes scheme (Anthes, 1977) performs better in simulating heating, moistening and precipitation rate in a moderate convective regime. A similar kind of study was conducted by Alapaty et al. (1994) using the Naval Research Laboratory/North Carolina State University (NRL/NCSU) nested grid regional model 
with Kuo and Betts-Miller schemes (Betts, 1993) during an active monsoon period; they reported that different regional monsoon features are better simulated with the Kuo scheme. Das et al. (2001) performed a sensitivity study of ISM to CCS using the global spectral model of the National Centre of Medium Range Weather Forecasting (NCMWRF), India, considering three CCS, viz. the simplified Arakawa-Schubert scheme (SAS), the relaxed Arakawa-Schubert scheme (RAS), and the Kuo scheme. They concluded that SAS performed better in simulating the regional features of ISM. Das et al. (2002) carried out another sensitivity study using the above CCS to observe the skill of medium range forecast over the Indian region which corroborates their previous findings.

Dash et al. (2006) investigated the sensitivity of ISM on cumulus convection for a four-yr. period (1993-1996) using RegCM3 and concluded that the Grell scheme (Grell, 1993; Grell et al., 1994) performed better. Martínez et al. (2006) observed that the Grell scheme with Arakawa-Schubert closure is better in simulating summer precipitation in the Caribbean region using RegCM3. Venkata and Cox (2006) inferred that the Kain-Fritsch scheme (Kain, 1993) performed better than the Grell scheme in simulating monsoon depression using a mesoscale model (MM5). In a recent study, Sinha et al. (2013) showed that the MIT scheme (Emanuel, 1991) is a better choice for the simulation of ISM. These studies clearly indicate that the monsoon features are highly sensitive to the choice of CCS. Although, a number of studies on the ISM have been conducted using regional models, but mostly with the Biosphere-Atmosphere Transfer Scheme (BATS) (Dickinson et al., 1993). No study has been conducted so far using RegCM4 in combination with other land surface schemes present in the model (e.g, the Community Land Model [CLM] v. 3.5) for the seasonal simulation of ISM.

In this study an attempt is made to test the sensitivity of the ISM simulation to some of the CCS that have not been considered in earlier studies. The following section contains three subsections in which the model is described, numerical experiments are conducted and datasets are used. Results and discussions are presented in Section 3, followed by a conclusion in Section 4.

\section{Model description, experimental design and datasets used}

\subsection{Model description}

The regional climate model (RegCM4, version 4.1.1), which is developed by the Abdus Salam International Center for Theoretical Physics (ICTP, Italy), is an evolution of RegCM3 with inclusion of some improved physical parameterization schemes. Its dynamical core is, as its previous version (Pal et al., 2007) a hydrostatic, primitive equation model which has a terrain-following sigma coordinate in the vertical. RegCM4 consists of multiple state-of-the-art physics options. Radiative transfer calculations follow the radiative transfer scheme of the global model CCM3 (Kiehl et al., 1996). Along with the planetary boundary layer (PBL) scheme proposed by Holtslag et al. (1990) and used in RegCM3, a new PBL scheme developed by the University of Washington (Bretherton et al., 2004) is implemented in RegCM4. The model also includes parameterization schemes for ocean fluxes, interactive aerosol schemes and interactive lake models.

In RegCM3, land surface processes were described using BATS (Dickinson et al., 1993). In addition, CLM3.5 (Tawfik and Steiner, 2011), developed by the National Center for Atmospheric Research (NCAR) is coupled with RegCM4 to improve the representation of land surface processes. CLM has the best capability to represent various land surface process like snow and soil layers, land surface heterogeneity, land cover types and vegetation fraction (Steiner et al., 2005). A detailed description of CLM3.5 implemented in RegCM4 is presented in Steiner et al. (2009) and Collins et al. (2006).

In the RegCM4 modeling framework, precipitation is classified broadly into two categories, viz. non-convective scale (grid-scale) and convective (sub-grid scale). The former, also known as large/ resolved scale precipitation is derived using the subgrid explicit moisture scheme (SUBEX; Pal et al., 2000) while the later (sub-grid scale) is explained using different CCS mentioned below. The SUBEX scheme accounts for the sub-grid variability in clouds by linking the average relative humidity of a grid cell to the cloud fraction and cloud water, whereas the precipitation produced by a CCS illustrates the effects of sub-grid scale convective clouds.

There are three major CCS available in RegCM4, viz. MIT (Emanuel, 1991), Grell (Grell, 1993; Grell 
et al., 1994), Kuo (Anthes, 1977). A Major improvement in RegCM4 is the option of choosing different CCS over land and ocean (mixed scheme), instead of using a single CCS over the whole model domain. The reason is the limited performance of CCS over land and ocean (Giorgi et al., 2012); therefore, in addition to the three main CCS, the model has two mixed convection schemes: Grell over land and MIT over ocean (GL_MO) and Grell over ocean and MIT over land (GO_ML).

In the Kuo scheme (Anthes, 1977), the convection is activated when the moisture convergence of a column exceeds a threshold value and vertical sounding is convectively unstable. A fraction of the moisture convergence moistens the column and the remaining forms precipitation. It is explicitly mentioned that the moisture convergence of an atmospheric column is computed considering the advective tendency of water vapor only. The latent heat due to condensation is distributed between the cloud top and bottom by a function that allocates the maximum heating to the upper portion of the cloud layer (Giorgi et al., 2011).

The second CCS option is the Grell scheme (Grell, 1993; Grell et al., 1994), which assumes that the convective cloud stabilizes the environment as fast as the non-convective cloud destabilizes it. It is a mass flux convection scheme that considers the cloud as a two steady-state circulation having an updraft and a penetrative downdraft. The updraft and downdraft are initiated at the level where the moist static energy is maximum and minimum, respectively. It works when a lifted air parcel in the updraft attains moist convection level. The mixing of cloudy and environmental air is possible except at the top and bottom of the circulation. The mass flux is assumed to be constant and no entrainment/detrainment is allowed through the cloud edges. The scheme is employed with a closure approximation such as the Arakawa and Schubert (Arakawa and Schubert, 1974; Grell et al., 1994) closure or the Fritsch and Chappell closure (Fritsch and Chappell, 1980).

The third CCS option is the MIT scheme (Emanuel, 1991; Emanuel and Zivkovic-Rothman, 1999), where it is assumed that the cloud mixing is highly episodic and inhomogeneous and convection is triggered when the level of neutral buoyancy is greater than the cloud base level. A part of the condensed moisture forms precipitation and the remaining part forms cloud between these two levels. The fraction of the total cloud base mass flux that mixes with the environment at each level is proportional to the change rate of undiluted buoyancy with altitude. A more detailed description of RegCM4 is available in Giorgi et al. (2012).

\subsection{Experimental design}

The configuration of the model used in the present study is given in Table I. The model domain ranges from $30-120^{\circ} \mathrm{E}, 15^{\circ} \mathrm{S}-45^{\circ} \mathrm{N}$ with $30-\mathrm{km}$ horizontal

Table I. Model overview for this study.

\begin{tabular}{ll}
\hline Contents & Description \\
\hline Model dynamics & Hydrostatic \\
\hline Model domain & $30-120^{\circ} \mathrm{E} ; 15-45^{\circ} \mathrm{N}$ \\
\hline Horizontal resolution & $30 \mathrm{~km}$ \\
\hline Vertical level & $\begin{array}{l}23 \text { (terrain-following sigma } \\
\text { level) }\end{array}$ \\
\hline Map projection & Lambert conformal \\
\hline $\begin{array}{l}\text { Central latitude and } \\
\text { longitude }\end{array}$ & $16^{\circ} \mathrm{N}, 75^{\circ} \mathrm{E}$ \\
\hline
\end{tabular}

\begin{tabular}{ll}
\hline $\begin{array}{l}\text { Lateral boundary } \\
\text { condition scheme }\end{array}$ & Relaxation, exponential \\
\hline $\begin{array}{l}\text { Model integration time } \\
\text { step }\end{array}$ & $30 \mathrm{~s}$ \\
\hline $\begin{array}{l}\text { Cumulus convection } \\
\text { scheme }\end{array}$ & $\begin{array}{l}\text { MIT, KUO, GRELL, GO_ } \\
\text { ML, GL_MO }\end{array}$ \\
\hline Land surface scheme & $\begin{array}{l}\text { Community Land Model } \\
\text { (CLM3.5; Oleson et al., }\end{array}$ \\
$\begin{array}{ll}\text { 2008) } \\
\text { Closure scheme }\end{array}$ & $\begin{array}{l}\text { Arakawa and Schubert } \\
(1974)\end{array}$ \\
\hline PBL scheme & $\begin{array}{l}\text { Holtslag scheme (Holtslag et } \\
\text { al., 1990) }\end{array}$ \\
\hline Ocean flux scheme & $\begin{array}{l}\text { Zeng's scheme (Zeng et al., } \\
1998)\end{array}$ \\
\hline $\begin{array}{l}\text { Radiative transfer } \\
\text { scheme }\end{array}$ & $\begin{array}{l}\text { CCM3 (Kiehl et al., 1996; } \\
\text { Giorgi et al., 2011) }\end{array}$ \\
\hline $\begin{array}{l}\text { Explicit moisture } \\
\text { scheme }\end{array}$ & SUBEX (Pal et al., 2000) \\
\hline
\end{tabular}


resolution and 23 vertical levels (Fig. 1). The initial and lateral boundary conditions are provided by global reanalysis datasets. Similar to the other regional model, RegCM4 is employed with a buffer zone of 12 grid points inside the lateral boundary (Wang et al., 2003; Giorgi et al., 2011). Different prognostic variables of the model, such as wind components, temperature, water vapor, etc., are nudged to the reanalysis data with an exponential nudging technique. The polygon inside the model domain (Fig. 1) represents the buffer zone selected for this study.

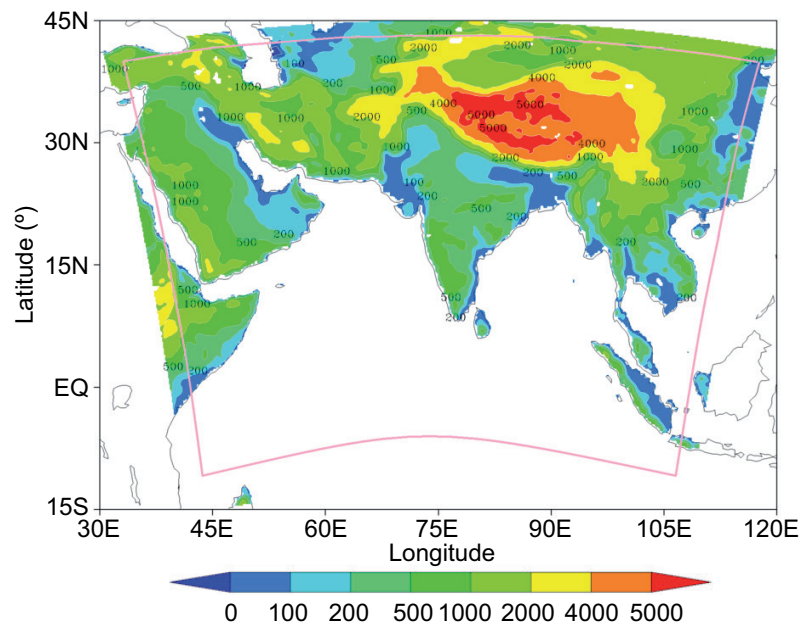

Fig. 1. Model domain and topography of the study region (in meters) along with buffer zone of the model.

The model is integrated from 00:00 UTC on May 1 to 18:00 UTC on September 30 for seasonal simulations of the ISM in 2007, 2008, and 2009. First, one month (May) is considered as the model spin-up period based on previous studies (e.g., Dash et al., 2006; Tchotchou and Kamga, 2010; Sinha et al., 2013; Zou et al., 2014; Tiwari et al., 2015); then, the simulation for the period June-September is considered for the analysis. Although spin-ups of regional models vary in the range of 10 days to one month (Wang et. al, 2003; Martínez et al., 2006; Zhong et al., 2006; Kang et al., 2014) and even longer for climate scale simulation, one month is sufficient for a seasonal scale (five months) simulation to achieve dynamical equilibrium of the model internal physics and lateral boundary conditions, as mentioned in the earlier literature. It is reported in an earlier study by Anthes et al. (1989) that regional models reach the equilibrium stage around 2-3 days. Five numerical experiments with five CCS (MIT, KUO, GRELL, GO_ML and GL_MO) for each of the three years $(2007,2008,2009)$ are conducted in this study. The Indian Meteorological Department (IMD) provides a detailed report regarding different features of the monsoon, including the indian summer monsoon rainfall (ISMR) for the years 2007-2009 at http:// www.imdpune.gov.in/Clim_Pred_LRF_New/Reports/Monsoon_Report/. As reported by the IMD, 2007 was an above-normal year with $105 \%$ of all India rainfall (long period average), 2008 was a normal year with $98 \%$ of all India rainfall, and 2009 was a deficit monsoon year with $77 \%$ of all India rainfall. The long period average rainfall is the average of the ISM precipitation for 1951-2000; it provides an opportunity to investigate the performance of RegCM4 in these three contrasting monsoon years.

\subsection{Datasets used}

The meteorological parameters for the initial and boundary conditions of the model were derived from the NCEP/NCAR reanalysis (Kalnay et al., 1996) at $2.5^{\circ} \times 2.5^{\circ}$ resolution. The geophysical parameters, viz. topography and land use, are obtained from United States Geological Survey (USGS) global data at 10 min resolution. Sea surface temperature (SST) for the model initial condition is taken from NOAA optimum interpolation $(\mathrm{OI})$ global data at $1^{\mathrm{o}} \times 1^{\mathrm{o}}$ resolution. Additional datasets including land cover, soil texture and color, leaf area index, etc., required for CLM, are obtained from http://clima-dods.ictp.it/ data/regcm $4 / C L M /$. Surface temperature and rainfall simulated by the model were validated with high resolution $\left(0.5^{\circ} \times 0.5^{\circ}\right)$ Climate Research Unit time series (CRU TS 3.22) datasets (Harris et al., 2014; Trenberth et al., 2014). Wind fields and different fluxes from the model simulation are compared with NCEP/NCAR datasets.

\section{Results and discussion}

The model-simulated results with different convection schemes are analyzed and presented to evaluate their performance in simulating important features of the monsoon and seasonal and monthly scale precipitation over India and its five homogeneous regions. At first, surface temperature is analyzed in reference to heat low, land-ocean temperature 
gradient and its spatial variation over the region in the monsoon season (section 3.1). Next, the monsoon circulation features in the three consecutive monsoon years are discussed in section 3.2. Rainfall distribution over India and its homogeneous regions is discussed in the subsequent section. The homogeneous regions considered for this study, viz. northwest India (NWI), west central India (WCI), central northeast India (CNEI), south peninsular India (SPI) and northeast India (NEI), are based on rainfall characteristics (Parthasarathy et al., 1994) (see Fig. 3). The model's ability to capture surface temperature and rainfall is also evaluated by means of different statistics such as spatial correlation, standard deviation and root mean square error (RMSE) using the Taylor diagram (Taylor, 2001), which provides pictorial representation of these features in a single diagram and is successfully used in numerous studies (Ali et al., 2015; Almazroui et al., 2016).

\subsection{Surface temperature}

Figure 2 presents June-September (JJAS) averaged temperature $\left({ }^{\circ} \mathrm{C}\right)$ for the years $2007-2009$ from model simulations using the MIT, GRELL, KUO, GO_ML and GL_MO schemes and the CRU dataset. It clearly indicates that the model using MIT, GO_ML and GL MO (KUO and GRELL), produces higher (lower) surface temperatures in all of three years compared to the CRU dataset over the whole domain, except peninsular India. Heat low over northwest India and Pakistan is reasonably well simulated using MIT, GO_ML and GL_MO. It is also observed that heat low is elongated to eastern India in the simulation with the MIT scheme. Temperature at the center of the heat low is overestimated in all of the three CCS (it varies in the range of $33-35^{\circ} \mathrm{C}$ in the CRU observation, which is more than $35^{\circ} \mathrm{C}$ in the model simulation). The region of heat low has larger spatial extent in the model simulation using the MIT scheme. Although higher surface temperature is noticed in the three schemes, MIT shows slightly higher $\left(2-3{ }^{\circ} \mathrm{C}\right)$ temperature. The strength of the heat low as well as the temperature over Indian landmass is not well simulated using GRELL and KUO.

The bias (observation-model) in the model simulated JJAS averaged surface temperature is analyzed in all of these years. For brevity, a figure is not presented as a part of the manuscript. A warm bias is observed in the model simulation with MIT and two mixed schemes, viz. GO_ML and GL_MO over most part of the Indian landmass. Although the pattern of the bias is similar in all of these three schemes, the magnitude is higher in MIT. This result is consistent with many previous studies (Zou et al., 2014; Tiwary et al., 2015).

The temperature bias varying in the range of $1-5^{\circ} \mathrm{C}$ (even more in some regions) is observed over large areas in different parts of India (NWI, north India, Gangetic West Bengal and central India) using MIT except in peninsular India, where a slight cold bias $\left(0.5-1^{\circ} \mathrm{C}\right)$ is observed. The temperature bias over the 4 regions using GO_ML and GL_MO (the mixed schemes) is found to be $0-3$ and $0-2^{\circ} \mathrm{C}$, respectively. A significant cold bias (more than $3{ }^{\circ} \mathrm{C}$ ) is observed in the simulation with KUO and GRELL. As a whole, the model using GL_MO reproduces the surface temperature better compared to MIT and GO_ML in each of the three years.

Biases in the model simulated surface temperature over different homogeneous regions (Fig. 3) of India using all the schemes (Table II) are analyzed to examine the model performance over different parts of India. It is clearly specified that the model shows a positive bias in the simulation with MIT in all the homogeneous regions except peninsular India in each of the three years. A significant negative bias is observed with KUO and GRELL over all of the homogeneous regions, with exception of 2008, when GRELL shows a slight warm bias over WCI. Although the signature of the positive/negative bias in the model simulated surface temperature over different regions varies form year to year, the detected magnitude of the bias is lower in $\mathrm{GO}_{-} \mathrm{ML}$ and GL_MO. No particular scheme has a better performance in all the regions. The model shows a better skill with GO_ML, GL_MO and MIT over NWI, CNEI SPI and NEI, respectively, irrespective of the years. Better performance is observed with GL_MO, GRELL and GO_ML in 2007, 2008 and

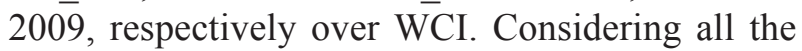
regions, the model performance is relatively better in the simulations with two mixed schemes, and specifically with GL_MO.

The Taylor diagram depicted in Figure 4 represents spatial correlation, standard deviation and RMSE between modeled and observed temperature (CRU). The design of the diagram considers the 


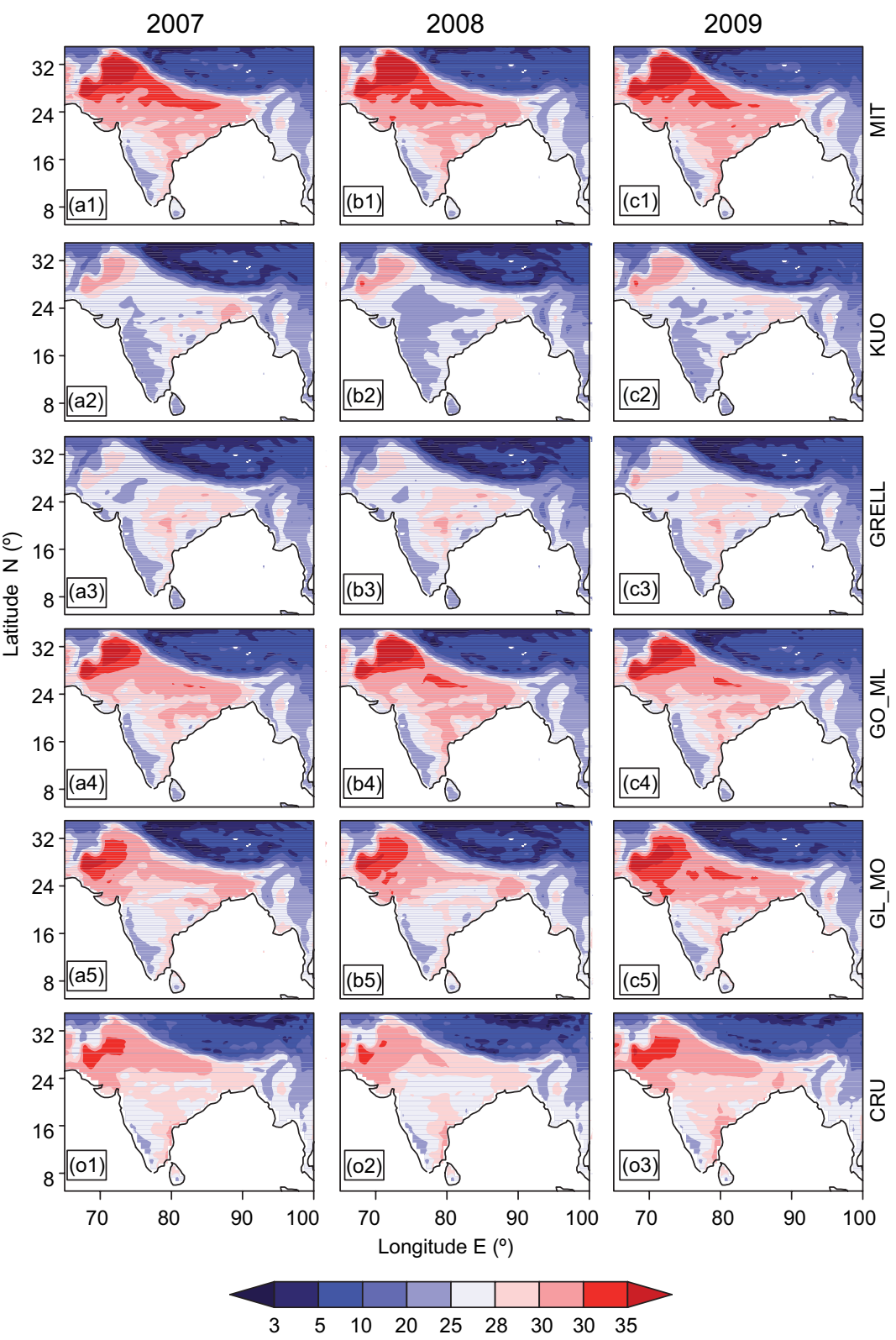

Fig. 2. JJAS averaged surface temperature (at 2 meter) for the year 2007, 2008, 2009 as obtained from model simulations and CRU dataset.

average of seasonal (JJAS) surface temperature for three years. It shows that the model performs reasonably well with all the CCS. The highest correlation $(\sim 0.97)$ and lowest RMSE $\left(\sim 2.1^{\circ} \mathrm{C}\right)$ are obtained using GL_MO, while the modeled standard deviation is almost equal to the observed one using KUO and GRELL. The other three schemes show a slightly higher standard deviation $\left(7.5^{\circ} \mathrm{C}\right)$, which infers that spatial distribution and accuracy are better simulated by the model with GL_MO followed by MIT and GO_ML, with slightly higher variations than the CRŪ observation.

Seasonally averaged (JJAS) sensible heat flux (SHF) simulated by the model using different convection schemes along-with NCEP/NCAR datasets is presented in Figure 5. A higher SHF is noticed in the model simulation with MIT and the two mixed schemes specifically over central and northwest 


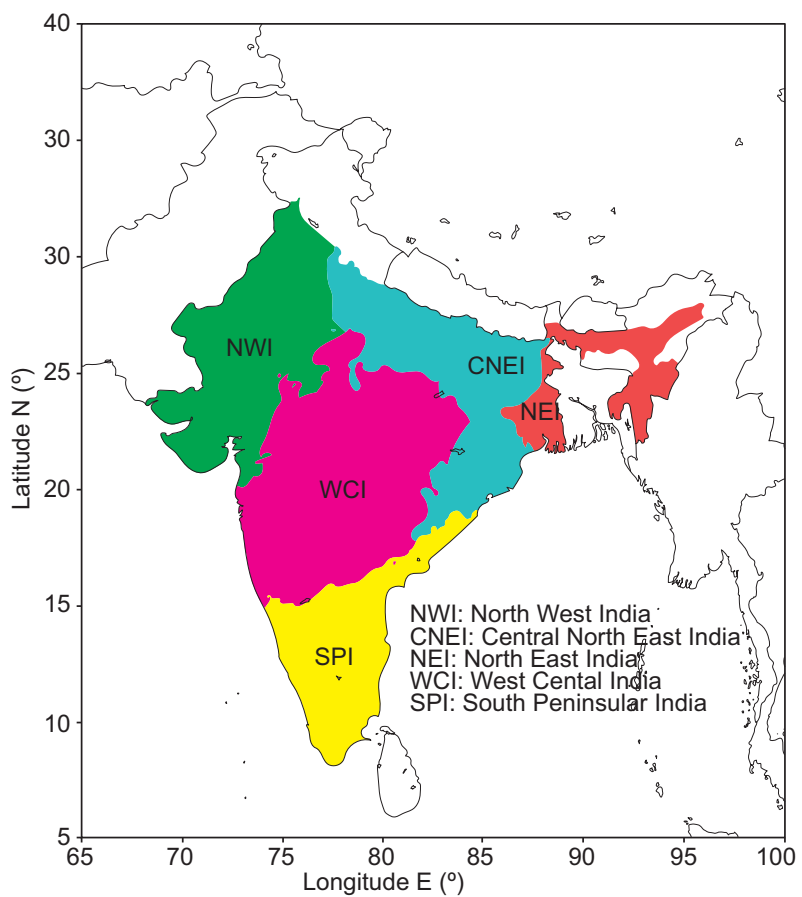

Fig. 3. Five homogeneous regions (Partahsarathi et al., 1994) over which performance of the convection schemes are evaluated.

India. The highest SHF is noticed using MIT, which may lead to model simulation of higher surface temperature with those schemes. A lower magnitude of SHF over Indian landmass is observed in the simulation with KUO, indicating lower surface temperature with that scheme. This result is consistent with an earlier study by Nayak et al. (2017). Analyzing seasonally averaged fractional cloud cover (figure not shown), it is observed that the model produces lower values using MIT compared with the other schemes. This indicates that a larger amount of solar radiation reaches the land surface and increases the SHF, which results in higher surface temperature in the model simulation with MIT.

The model-simulated monthly mean surface temperature for JJAS (figure not shown) in 2009 (a draught year) shows a weaker heat low located over a smaller area. This is in agreement with the IMD monsoon report for that year. Dynamics of the monsoon circulation mostly depend upon the land ocean temperature gradient over the Indian subcontinent during the monsoon period. To analyze this aspect, four grid boxes (based on Mohanty et al., 2002) are introduced as shown in Figure 6, Box1
Table II. Scheme-wise bias of surface temperature during 2007-2009 over different homogeneous regions.

\begin{tabular}{lrrrrr}
\hline & NWI & WCI & CNEI & SPI & NEI \\
\hline \multicolumn{5}{c}{2007} \\
\hline MIT & -1.87 & -1.45 & -2.48 & 0.42 & -1.11 \\
KUO & 4.12 & 2.43 & 2.31 & 2.86 & 1.34 \\
GRELL & 5.12 & 0.64 & 1.82 & 2.02 & 2.01 \\
GO_ML & 0.03 & -0.57 & -1.44 & 1.16 & 0.02 \\
GL_MO & -0.47 & 0.34 & -0.27 & 0.99 & -0.38 \\
\hline \multicolumn{7}{c}{2008} \\
\hline MIT & -3.01 & -2.40 & -2.90 & 0.27 & -0.69 \\
KUO & 3.97 & 3.10 & 2.33 & 2.88 & 1.78 \\
GRELL & 3.93 & -0.01 & 1.11 & 2.25 & 2.44 \\
GO_ML & -1.28 & -1.66 & -2.36 & 0.98 & -0.02 \\
GL_MO & -1.78 & -0.18 & -0.13 & 1.27 & 0.31 \\
\hline \multicolumn{7}{c}{2009} \\
& -1.62 & -1.64 & -1.93 & 0.11 & -0.76 \\
MIT & 4.30 & 3.55 & 2.96 & 3.48 & 1.76 \\
KUO & 4.64 & 1.13 & 2.21 & 2.47 & 2.65 \\
GRELL & 0.05 & 0.14 & -1.05 & 1.64 & 0.46 \\
GO_ML & -1.39 & -0.80 & -1.14 & 0.92 & -0.18 \\
GL_MO & & & & \\
\hline
\end{tabular}

NWI: Northwest India; WCI: west central India; CNEI: central northeast India; SPI: south peninsular India; NEI: northeast India.

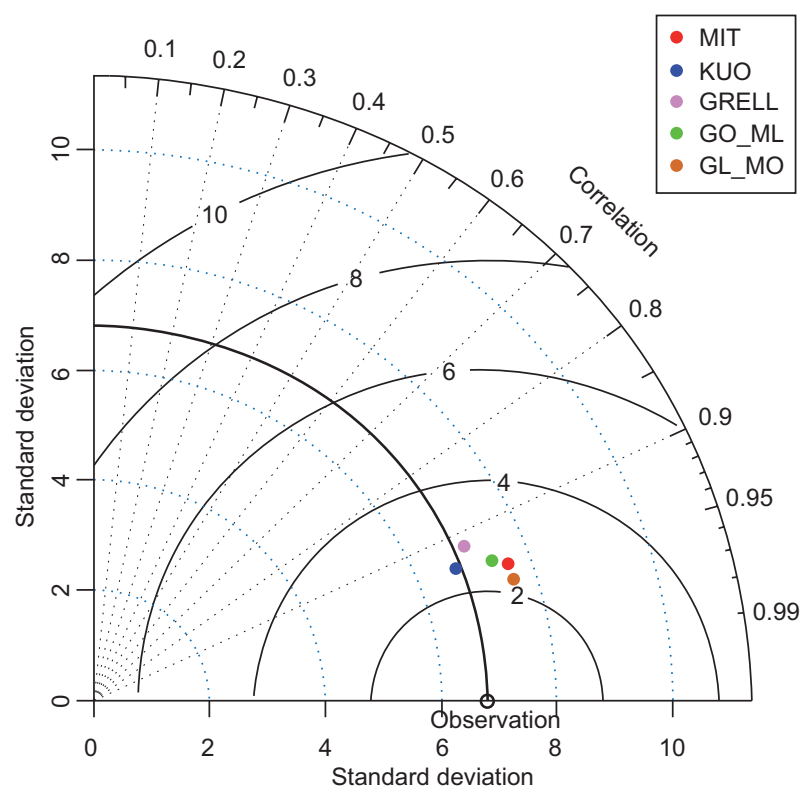

Fig. 4: Taylor Diagram of JJAS surface temperature averaged for three years. 


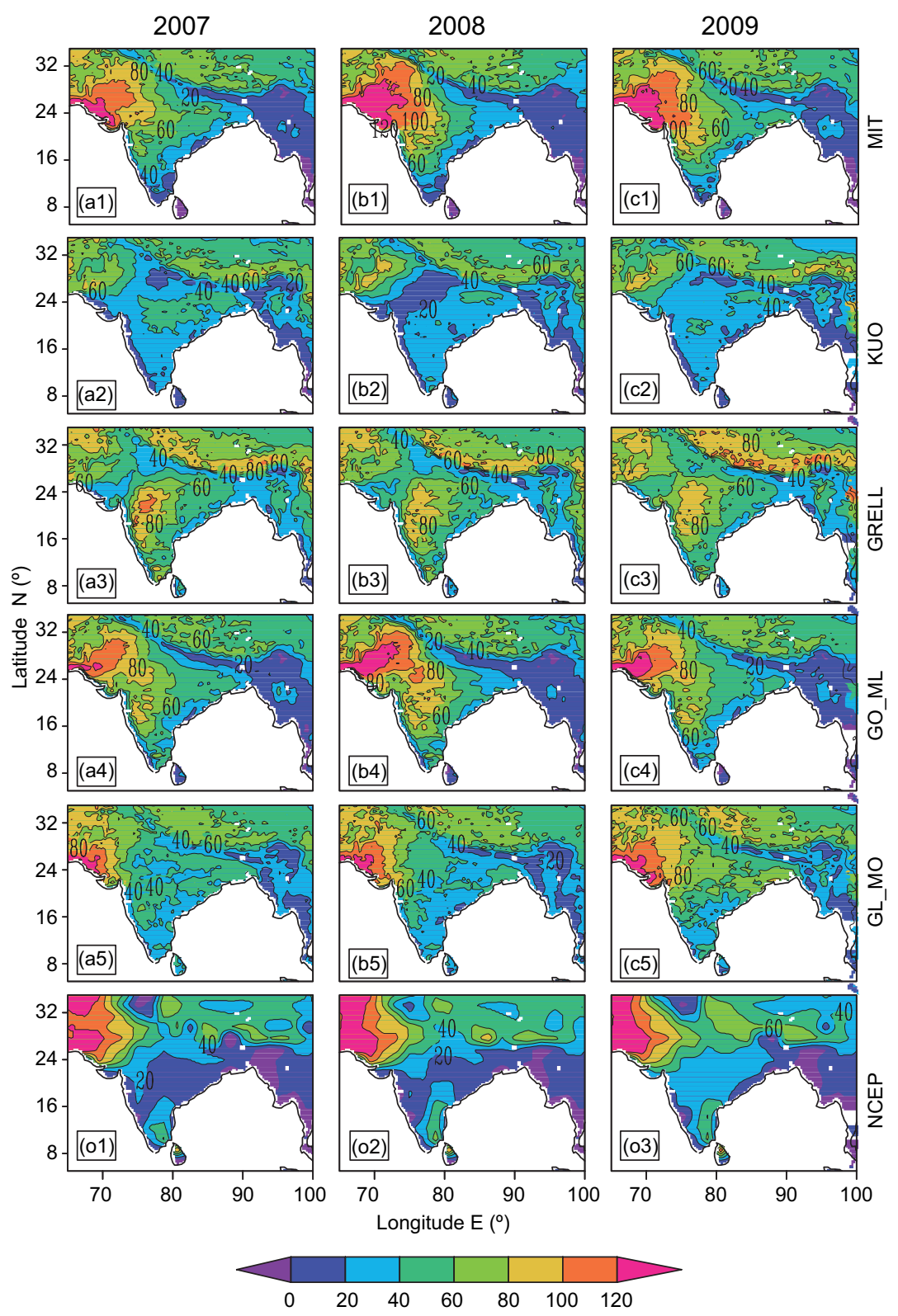

Fig. 5. JJAS averaged sensible heat flux $\left(\mathrm{W} / \mathrm{m}^{2}\right)$ for the year 2007, 2008, 2009 as obtained from model simulations and NCEP reanalysis dataset.

over NWI $\left(70-75^{\circ} \mathrm{E}, 28-32^{\circ} \mathrm{N}\right)$, where the heat low dominates during monsoon season; Box 2 over central India $\left(72.5-82.5^{\circ} \mathrm{E}, 17.5-27.5^{\circ} \mathrm{N}\right)$; Box3 over the Arabian Sea $\left(60-70^{\circ} \mathrm{E}, 10-20^{\circ} \mathrm{N}\right)$ near the east of Somalia coast, and Box 4 over the Bay of Bengal $\left(85-95^{\circ} \mathrm{E}, 10-20^{\circ} \mathrm{N}\right)$. The differences in the area averaged surface temperatures between these boxes in the month of May are computed and compared with NCEP/NCAR data due to non-availability of
CRU temperature data over the oceanic region. The temperature differences between Box 1 and Box 3 in 2007 (a normal monsoon year) and 2009 (a deficit monsoon year) are 5.19 and $5.11^{\circ} \mathrm{C}$, respectively, in the simulation using MIT, whereas in the NCEP/ NCAR reanalysis datasets they are 3.27 and $3.28^{\circ} \mathrm{C}$, respectively. This implies that the model is able to reproduce the temperature gradient for the two contrasting years better than NCEP datasets. The 


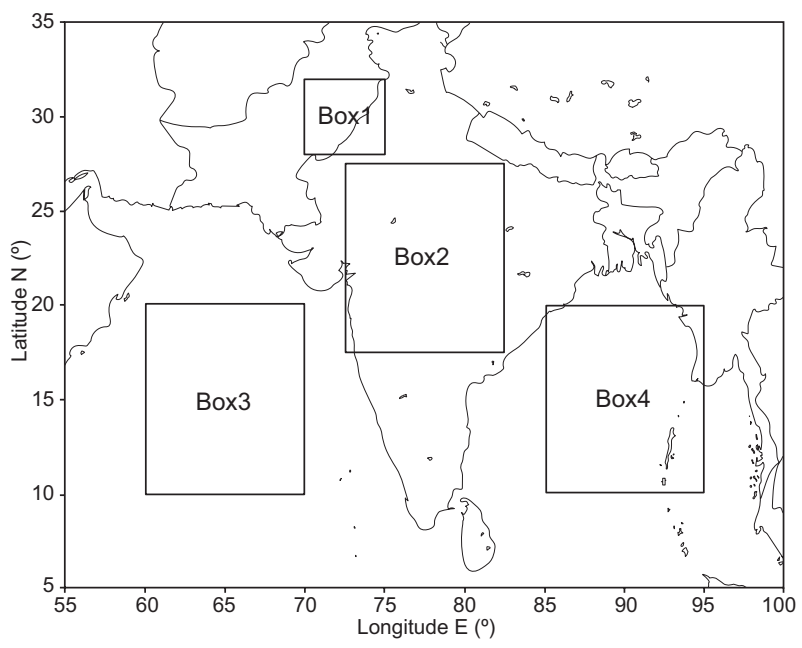

Fig. 6. Four grid boxes considered in calculating land ocean temperature gradient.

temperature difference between Box 2 and Box 4 in the simulation using MIT and NCEP data are $2.18^{\circ} \mathrm{C}$, $5.2^{\circ} \mathrm{C}$, respectively in 2007 , and $4.44^{\circ} \mathrm{C}, 5.5^{\circ} \mathrm{C}$, respectively in 2009 , which clearly indicates that the temperature gradient between central India and the Bay of Bengal shows inverse relationship with that between NWI and the Arabian Sea in contrasting monsoon years.

\subsection{Monsoon circulation}

\subsubsection{Low level winds $(850 \mathrm{hPa})$}

Figure 7 presents the seasonal (JJAS) winds at 850 hPa computed from model simulations and NCEP/ NCAR reanalysis for the years 2007-2009. The three columns of Figure 7 represent the simulation in three different years while the six rows correspond to five CCS and the reanalysis datasets. The model is able to simulate low-level circulation features such as the Somali jet stream, strong westerly winds over the Arabian Sea, the cross equatorial flow, the westerly flow over Indian landmass, etc., in all of the years with all of the schemes. It is also worth to mention that the performance of RegCM4 in simulating low-level circulation is comparatively better with MIT than with other schemes. Although the model underestimates the strength of the winds over both land and ocean in every CCS, it is lower in MIT followed by GO_ML and GL_MO. KUO and GRELL produce significantly weaker $\left(5-8 \mathrm{~m} \mathrm{~s}^{-1}\right)$ winds over the entire model domain.
In the year 2007, the strength of the Somali jet and cross equatorial flow are found to be 16 and $10 \mathrm{~m} \mathrm{~s}^{-1}$, respectively, in the simulations with MIT, while the same are found to be 18 and $10 \mathrm{~m} \mathrm{~s}^{-1}$ in the NCEP reanalysis data and in the range of $8-12 \mathrm{~m} \mathrm{~s}^{-1}$ in all other schemes. The westerly flow over the Arabian Sea and southern peninsular India simulated by the model is weaker except with MIT. The flow over the Bay of Bengal is also reasonably well simulated by the model with MIT (maximum strength is $\sim 10 \mathrm{~m} \mathrm{~s}^{-1}$ ). Moreover, the area over which strong wind is simulated by the model agrees well with the reanalysis though the spatial extent differs.

The model exhibits similar performance in 2008 and 2009. However, the monthly average winds (figure not shown) for August and September 2009 show that the low-level wind is significantly weaker compared to that in 2007 in the simulation with MIT. The difference between model-simulated seasonal winds in 2007 and 2009 (figure not shown) shows that the strength of the Somali jet in 2009 is 2-3 $\mathrm{m} \mathrm{s}^{-1}$ weaker than in 2007 in the simulation with MIT, GL_MO, and GO_ML. Another interesting fact to be mentioned here is that unlike the reanalysis datasets, RegCM4 with MIT could simulate stronger westerly winds over the Bay of Bengal in 2009 than in 2007 and 2008, which is consistent with the findings of Raju et al. (2010) and Mohanty et al. (2005). This indicates that the model with the above mentioned schemes could be able to simulate the differences in wind magnitudes during contrasting monsoon years. With GRELL and KUO, the model does not simulate this contrasting feature.

It is important to note that low-level winds in the RegCM4 simulation with all CCS is weaker compared to reanalysis data. In particular, the region of the south easterly flow before crossing the Equator shows smaller spatial coverage in the model simulation than in NCEP/NCAR data. This weaker wind flow favors a weaker Somali jet in the simulation, which may lead to less supply of moisture to the Indian landmass. Underestimation of low-level winds in the RegCM simulation is also observed and discussed in Sinha et al., 2013. In addition, a close inspection reveals that the circulation over central India shows an anti-cyclonic structure, which may hamper the moisture pulling mechanism from the neighboring ocean and lead to suppress the convective activity. 
This positive feedback between convective rainfall and low-level southwesterly winds is discussed in previous studies (Zou and Zhou, 2013; Zou et al., 2014). Overall, the model reproduces the low level-wind reasonably well with MIT compared to other schemes.

\subsubsection{Upper level winds $(850 \mathrm{hPa})$}

Seasonal winds at $200 \mathrm{hPa}$ as obtained from model simulations and NCEP/NCAR reanalysis are shown in Figure 8. As mentioned in section 4.2.1, columns in Figure 8 represent the winds in three different years and rows depict the winds with five CCS and

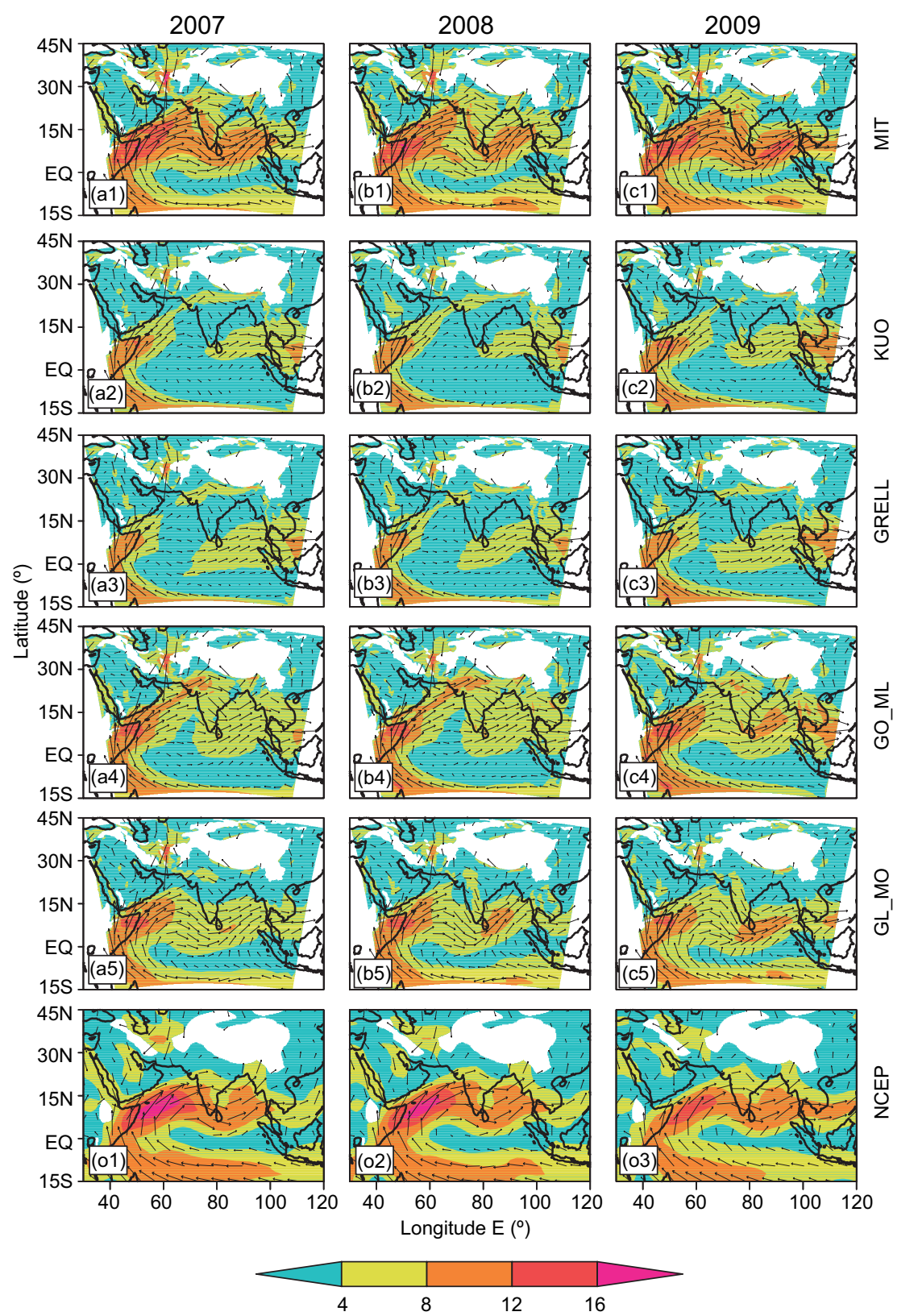

Fig. 7. JJAS averaged lower level wind (at $850 \mathrm{hPa}$ ) for the year 2007, 2008 and 2009 as obtained from model simulations and NCEP/NCAR reanalysis. The colour shading represents the magnitude of the wind $\left(\mathrm{m} \mathrm{s}^{-1}\right)$ and the arrows are the direction. 
the reanalysis. Important upper level circulation features during ISM are the Tibetan anticyclone, the subtropical westerly jet (STWJ) and the tropical easterly jet (TEJ). Although the circulation pattern is well simulated by the model with all of the schemes, scheme-wise variation is noticed in terms of strength at the core of these wind jets, their respective position and spatial extent. As seen in the case of low level wind, RegCM4 shows better skill with MIT in simulating upper level circulation compared to other available CCS.

The location of the TEJ is well simulated by the model with MIT, though its strength is slightly overpredicted in all the years. TEJ is clearly observed from Thailand and Indonesia and is extended up to the east coast of South Africa covering the southern

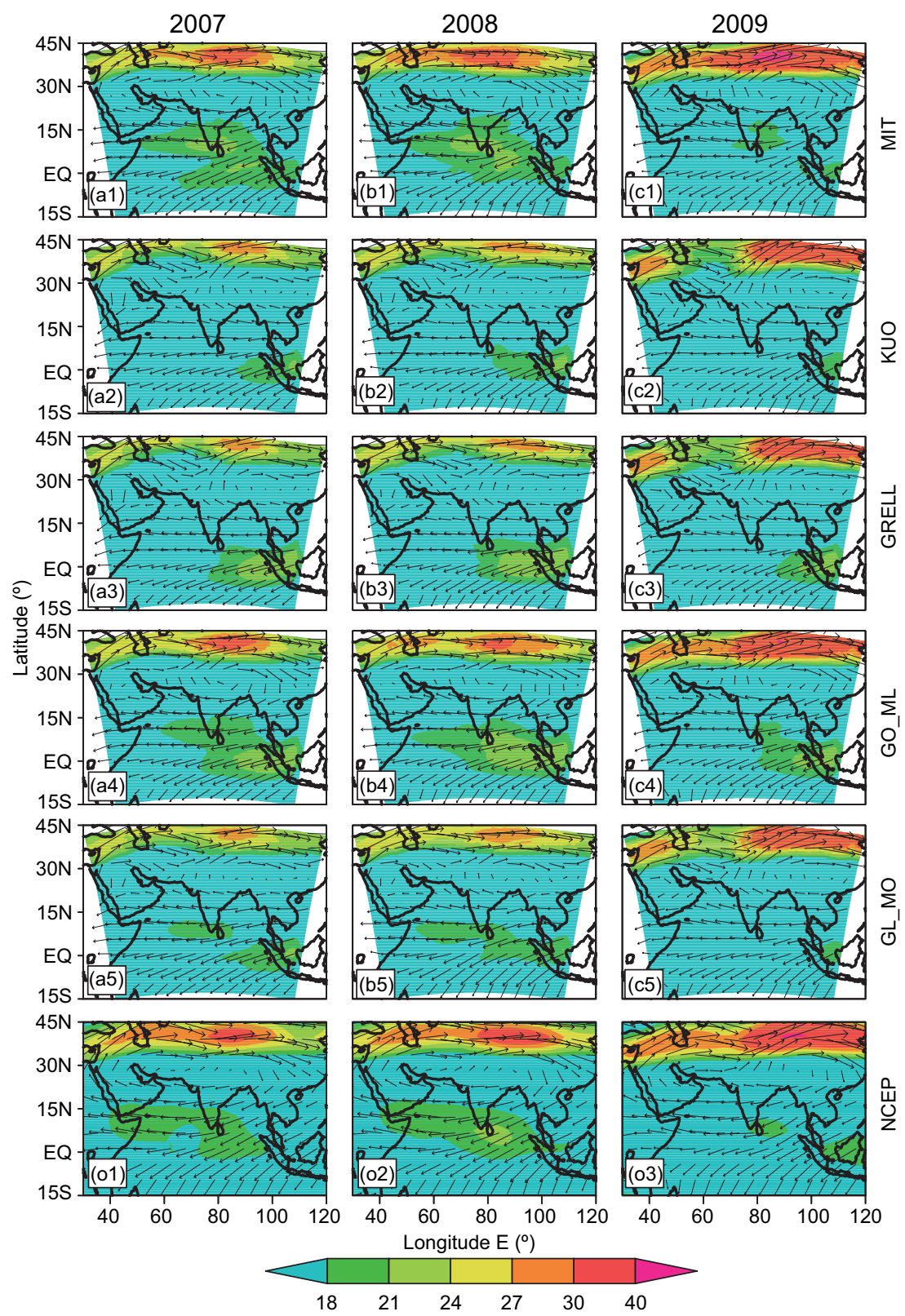

Fig. 8. JJAS averaged upper level wind (200hPa) for the year 2007, 2008, 2009 as obtained from model simulations and NCEP/NCAR reanalysis. The colour shading represents the magnitude of the wind $\left(\mathrm{m} \mathrm{s}^{-1}\right)$. 
part of Indian landmass in the model simulation with MIT during normal monsoon years $(2007,2008)$.

The magnitude of the wind at the core of the TEJ in the simulation with MIT and NCEP data is about $20 \mathrm{~m} \mathrm{~s}^{-1}$. The strength of the TEJ is underpredicted and its position is moved eastward of its normal position $\left(80^{\circ} \mathrm{E}, 5-10^{\circ} \mathrm{N}\right)$ in the simulation with GRELL and KUO. The model could be able to reproduce TEJ using GO_ML but fails in the simulation using GL_MO in all of the three years. It is interesting to note that the spatial extent of TEJ is less in 2009 (a deficit monsoon year) compared to 2007 (above normal year) and 2008 (normal year) in MIT, which agrees well with reanalysis data. Moreover, the strength of TEJ at the southern peak of Indian Peninsula is higher in 2007 and 2008 compared to 2009 in the model simulation using MIT, which is in good agreement with the reanalysis data. This infers that the model is able to simulate the contrasting monsoon features of upper level wind using MIT. These findings agree with Sinha et al., 2013.

The SWTJ is also reasonably well simulated by the model with all the schemes but slightly better with MIT. The STWJ is located to the north of the Himalaya (around $40^{\circ} \mathrm{N}$ ) in all years. The magnitude at the core of STWJ in the simulation using MIT as well as reanalysis data is about $32 \mathrm{~m} \mathrm{~s}^{-1}$ but the core is more spatially extended in the model simulation. As noticed previously, in case of TEJ, the strength of the SWTJ is also significantly weaker in the simulations using other schemes. This clearly shows that the intensity of SWTJ is greater in deficit years (2009) than in normal or above normal years (2007 and 2008), which is in good agreement with Sinha et al., 2013. Unlike the reanalysis datasets, in the model simulation with MIT the center of the Tibetan anticyclone is prominently well positioned at about $30^{\circ} \mathrm{N}, 85^{\circ} \mathrm{E}$. It is notably weaker and is not clearly visible in other CCS. The model was not able to show its shifting eastwards in 2009 as compared to 2007 and 2008 using MIT.

Considering overall performances, the characteristic features of the upper level wind as well as circulation are reasonably well simulated by the model with MIT.

\subsection{Rainfall distribution}

Rainfall is one of the most significant climatic parameters due to its huge societal impact. As reported in Almazroui et al. (2016), it is the most difficult-to-estimate parameter in the evaluation of a regional model due to its significant spatio-temporal variation, uncertainty and biases (Almazroui, 2013; Islam, 2009). Therefore, better simulation of rainfall using different CCS within a modeling framework remains always a challenge to climate researchers since its inception. In this section, model simulated rainfall using five CCS is analyzed and discussed.

Seasonal monsoon (JJAS) precipitation for the years 2007-2009, as obtained from the model simulations and CRU rainfall datasets, is presented in Figure 9. Rows in the figure represent the rainfall using different CCS and CRU rainfall, while columns show the rainfall in three different years. It clearly indicates that rainfall is underestimated by the model with all the schemes, particularly over central and NWI in all the years. The magnitude of this underestimation varies from scheme to scheme with reference to CRU rainfall. However, the rainfall is better simulated by the model with MIT and GO_ML compared to other CCS. It is noticed that the model with the above mentioned schemes correctly simulates the two rainfall maxima zones (Ratnam and Kumar, 2005): one over western Ghats and another over NEI and foothills of the Himalaya (Fig. 9), which is in good agreement with CRU data. Significant underestimation is observed in the simulation using GRELL and KUO, particularly over central India, where the simulated rainfall is less than $1 \mathrm{~mm}^{\text {day }}{ }^{-1}$.

Model biases (observation-model) in the simulation of seasonal rainfall for the above mentioned years are given in Figure 10. The model using all schemes shows a dry bias over large part of Indian landmass, Bangladesh, Myanmar and Thailand in all three years. The magnitude of the bias is comparatively lower in the simulation using MIT, GO_ML and GL_MO. The region over which significant dry bias $\left(5 \mathrm{~mm}\right.$ day $\left.^{-1}\right)$ is noticed extends wider when KUO and GRELL are used. The model shows a wet bias of 0-5 mm day ${ }^{-1}$ using MIT and GO_ML over foot hills of the Himalaya and hilly regions of NEI. It is also noticed that with MIT and GO ML the model shows a wet bias of 0-1 mm day ${ }^{-1}$ over some parts of the Indian peninsula, particularly in the rain shadow region of western Ghats except during 2007, when a dry bias is observed using GO_ML. Comparison of the simulations using MIT and GO_ML indicates that 


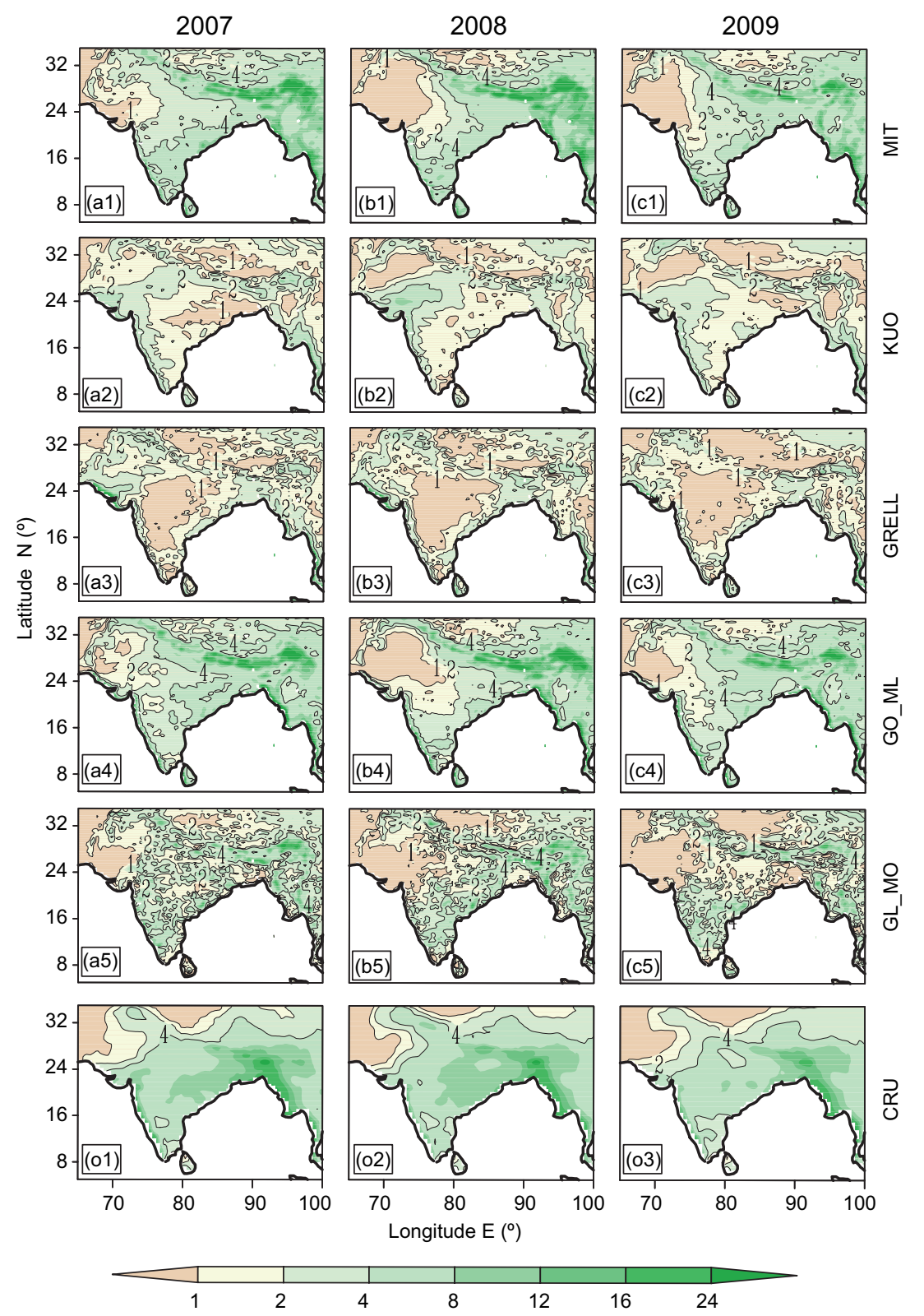

Fig. 9. JJAS averaged rainfall for 2007, 2008 and 2009 as obtained from model simulations and CRU datasets in $\mathrm{mm} \mathrm{day}^{-1}$.

the dry bias is less over central India when GO_ML is used except in 2008.

Similar biases are noticed in Nayak et al. (2017) and Maity et al. (2017). The simulation using GO $\mathrm{ML}$ is more realistic in representing precipitation. The analysis of model bias over different homogeneous regions (Fig. 3) reveals underestimation of rainfall using all the schemes and in all the homogeneous zones (tables not shown). Only a slight overprediction is observed in 2008 in SPI and NEI, which indicates that model performance is comparatively better with MIT and GO_ML than with the other schemes except in NWI, where KUO performs better.

The difference in the model simulated rainfall between 2007 and 2009 (figure not shown) is analyzed to understand the fidelity of the model in producing yearly variations. It is observed that the model is able to simulate less rainfall in 2009 compared to 2007 


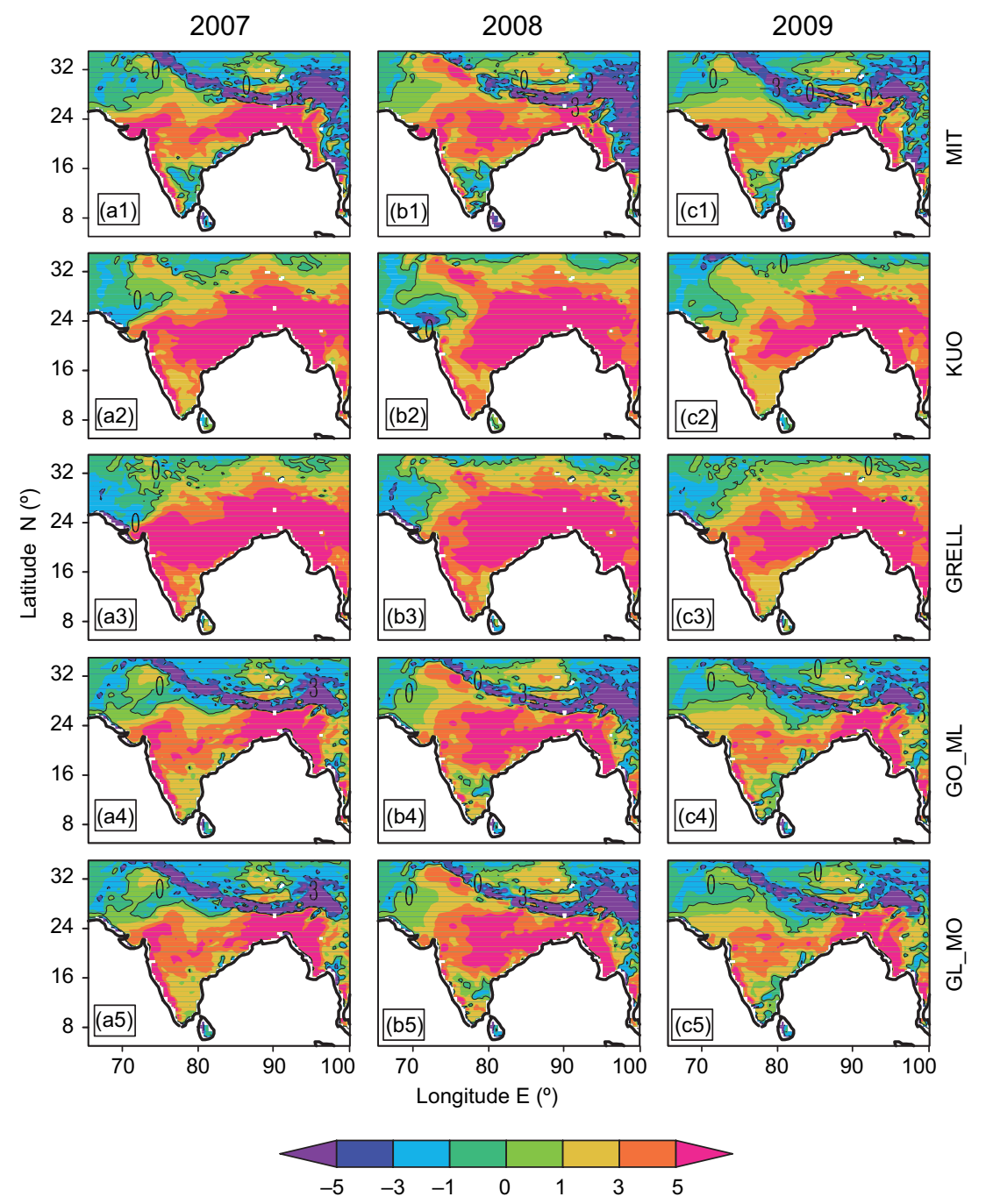

Fig. 10. Model bias for JJAS averaged rainfall for 2007, 2008 and 2009 as obtained from model simulations in $\mathrm{mm} \mathrm{day}^{-1}$.

over NWI, peninsular India, foothills of the Himalaya and NEI using MIT and GO_ML. The rainfall difference is minimal and not distinguishable in the model simulation using KUO and GRELL.

The monthly distribution (JJAS) of the ISMR for the years 2007-2009 from model simulations and CRU rainfall datasets is analyzed. For brevity, only the model results of 2007, along with CRU datasets are presented in Figure 11. Regardless of schemes and years, rainfall is underpredicted by the model using all the schemes, but is better represented with MIT and GO_ML. The model was unable to capture the monthly variation of rainfall in any of the years even with MIT and GO_ML. For example, in 2009, the model shows abundant rainfall in August and November, but according to the IMD report, rainfall in those months was significantly diminished $(73 \%$ and $80 \%$ ), which implies that the variation produced by the model is in contrast with the report of the IMD. Monthly rainfall is significantly underpredicted by the model with KUO and GRELL. The correlation coefficient and standard error in the monthly scale rainfall with CRU datasets shows that the model simulates more realistic rainfall with GO_ML.

A Taylor diagram for three years average of seasonal (JJAS) rainfall, which is presented in Figure 12, shows that the distribution of rainfall is well simulated by the model using GO_ML and MIT 

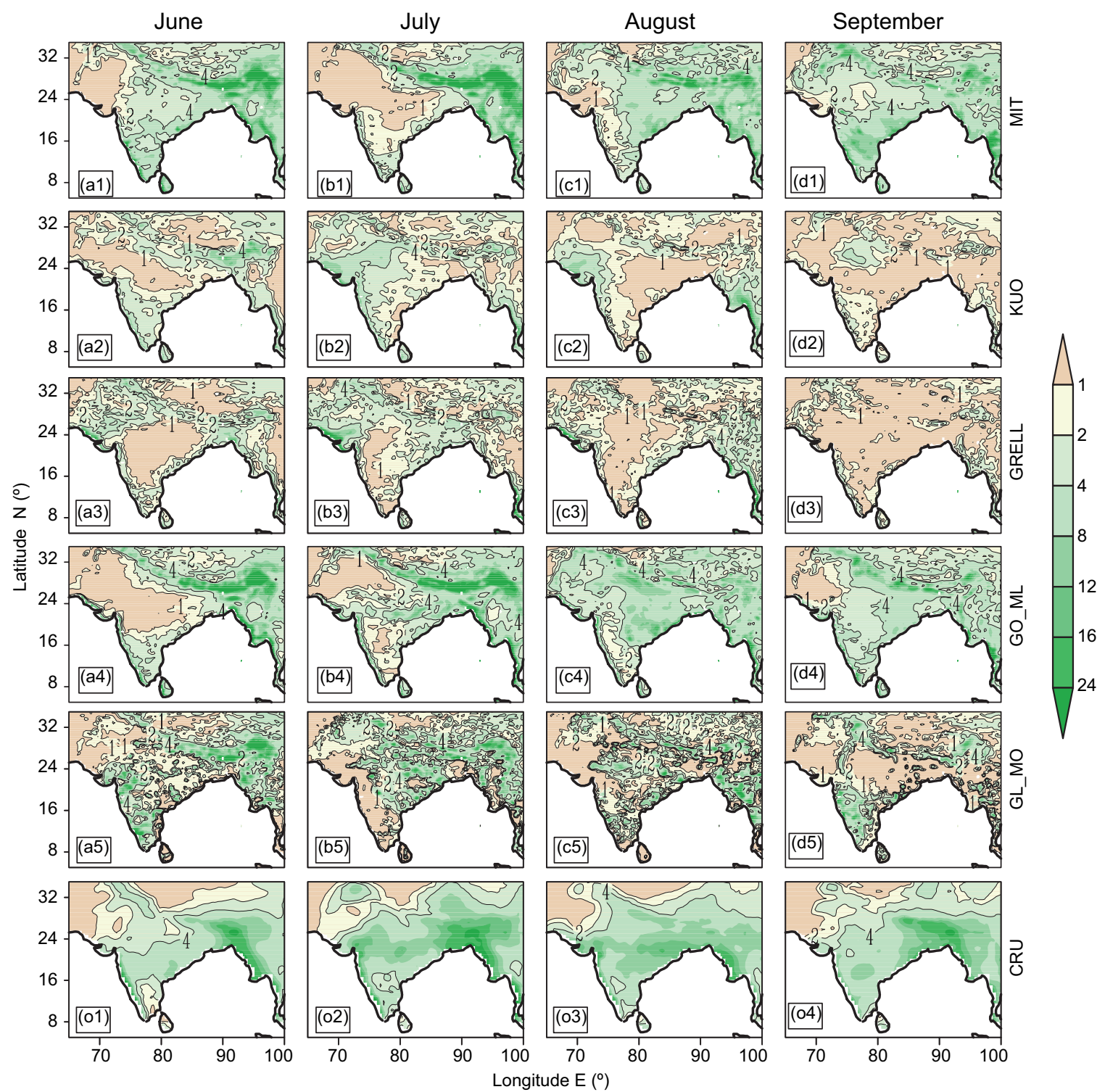

Fig. 11. Monthly rainfall as obtained from model simulations and CRU datasets for the year $2007 \mathrm{in} \mathrm{mm} \mathrm{day}{ }^{-1}$..

compared to other schemes. These two schemes show a comparatively higher correlation $(\sim 0.55)$, lower $\operatorname{RMSE}\left(\sim 4.4 \mathrm{~mm} \mathrm{day}^{-1}\right)$ and lower standard deviation $\left(\sim 4.5 \mathrm{~mm} \mathrm{day}^{-1}\right)$ than the other CCS. The performance of GO_ML is better than MIT as seen from the diagram, with slightly higher correlation and lower RMSE.

The correlation and RMSE of monthly rainfall is also analyzed (figure not shown). It is worth to mention that simulated rainfall is well distributed with KUO, particularly in June of 2007 and 2009. In a monthly scale, GO_ML shows better performance than MIT.
The magnitude of rainfall is also better simulated by the model using GO_ML and MIT compared to other schemes. Overall, the distribution and magnitude of rainfall is better simulated by the model using GO_ML.

The ISMR shows considerable spatial variation, therefore it is important to investigate the capability of the model to simulate rainfall in different homogeneous regions. Model simulated mean seasonal (JJAS) rainfall along with CRU data, averaged for five homogeneous regions with the five convection schemes, is presented in the Figure 13. Rainfall over all the homogeneous zones is underestimated by the 


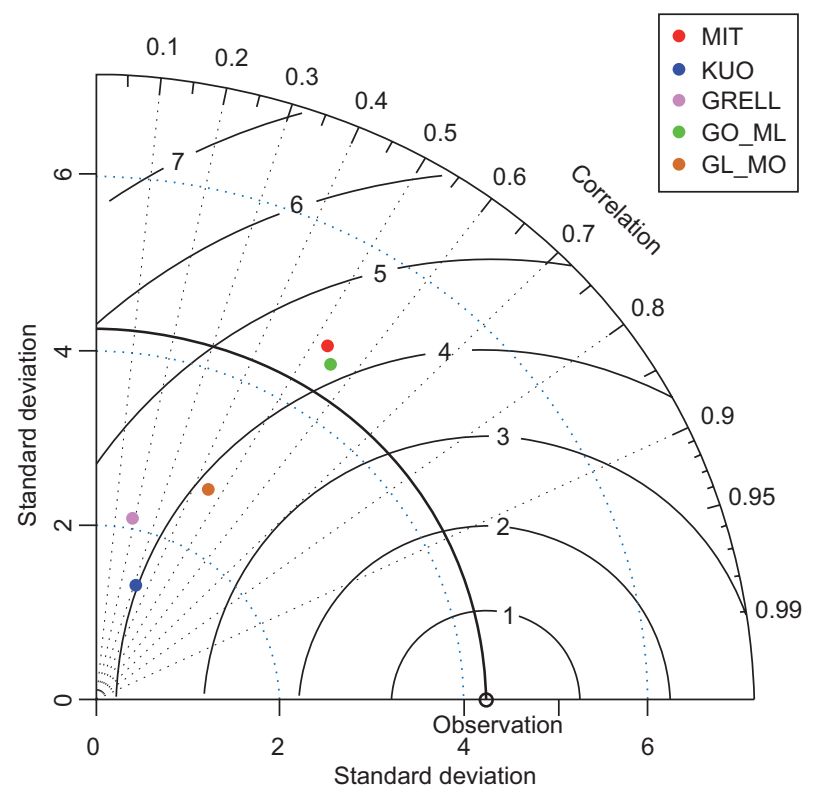

Fig. 12. Taylor Diagram of JJAS rainfall averaged for three years. model using all schemes. Rainfall over WCI and CNEI is significantly underpredicted by the model except in 2009, when the model is able to simulate rainfall reasonably well using MIT and GO ML over CNEI. Interestingly, the model performed consistently well with KUO over NWI. Figure 13 also indicates that seasonal rainfall is better simulated over different homogeneous regions in India using GO_ML and MIT compared to other schemes. Significant underprediction is observed with GRELL and KUO over all the homogeneous regions except NWI. The model shows less precipitation in 2009 compared to 2007 using MIT over NWI, WCI, NEI, SPI; the exception is CNEI, where it shows overprediction. Similarly, the simulation with GO_ML shows underprediction over NWI, WCI and CNEI and NEI and overprediction over SPI in 2007 and 2009.

The above discussion indicates that the model shows a dry bias using all schemes but exhibits better
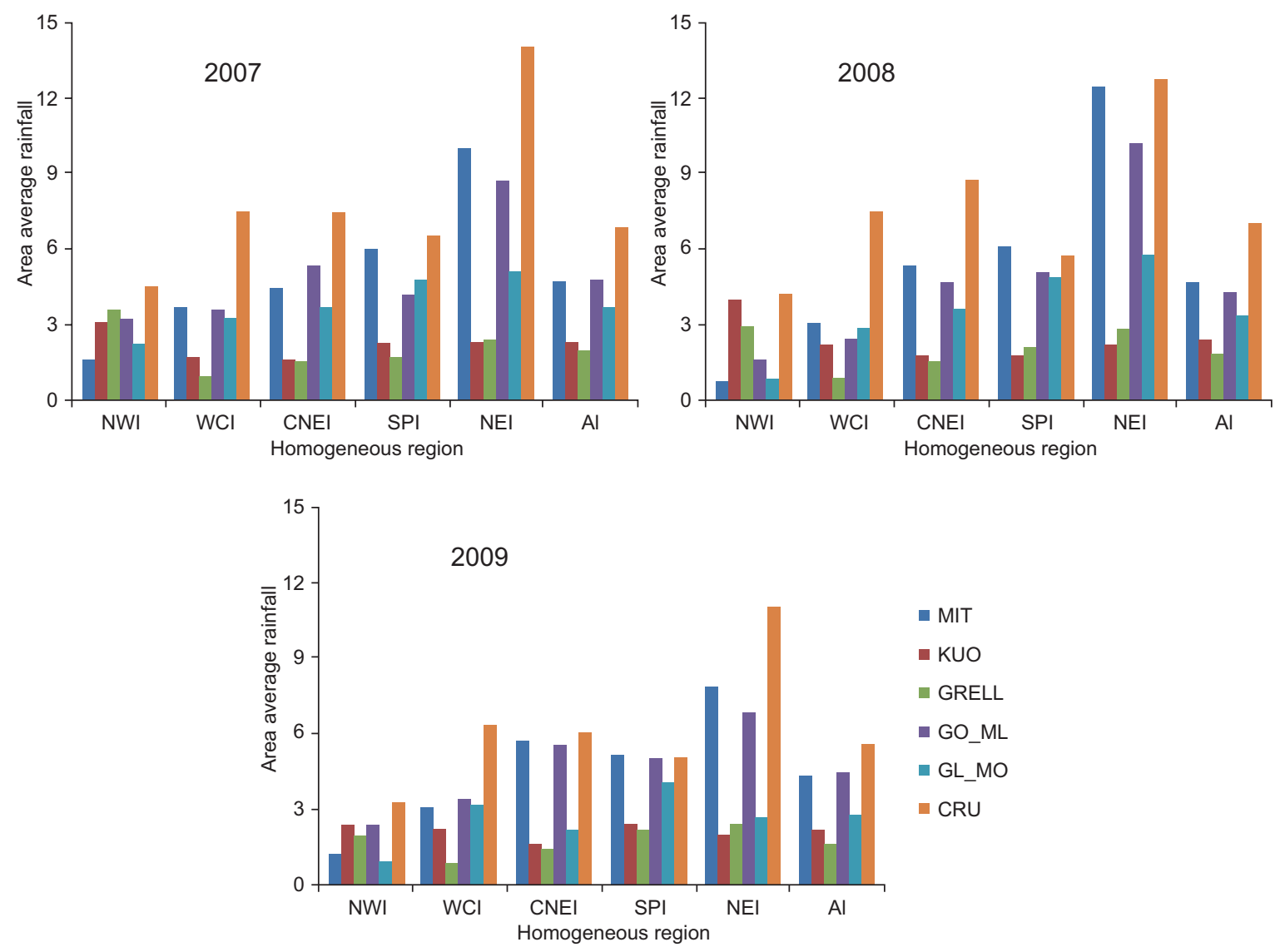

Fig. 13. Area averaged rainfall $\left(\mathrm{mm} \mathrm{day}^{-1}\right)$ for five homogeneous regions. 


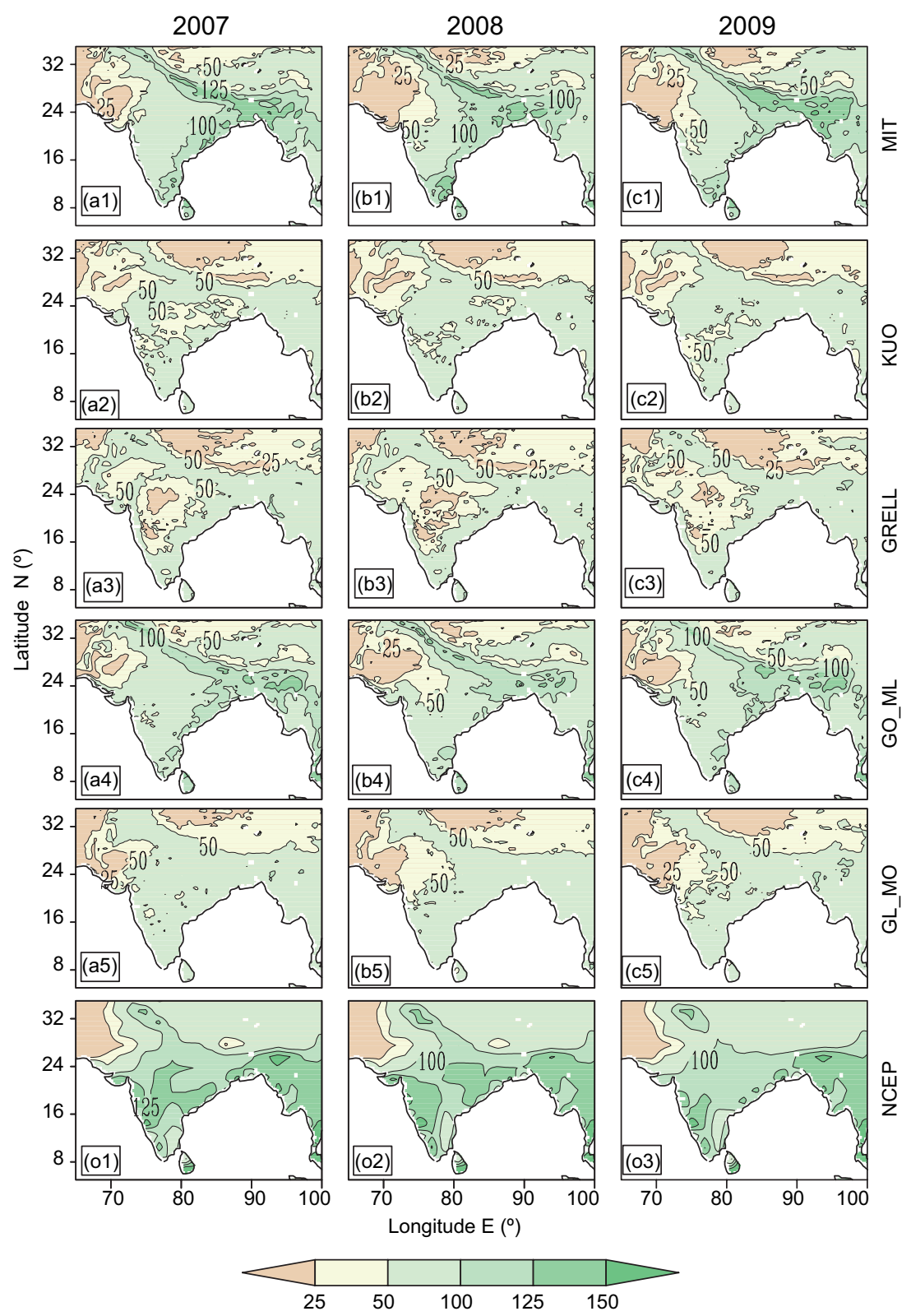

Fig. 14. JJAS averaged latent heat flux (W/m²) for the year 2007, 2008, 2009 as obtained from model simulations and NCEP reanalysis dataset.

performance with MIT and GO_ML in simulating rainfall both in monthly and seasonal scales. Figure 14 represents model simulated seasonal average latent heat flux (LHF) with all schemes and NCEP data. It shows that lower LHF is simulated by the model with all schemes. A lower LHF may lead to less moisture availability at the surface resulting in a dry bias within the model simulation. It is also noticed from the figure that the simulated LHF is closer to
NCEP data over foot hills of the Himalaya and NWI. Higher LHF enhances the rainfall simulation, which results in a wet bias over those regions using MIT and GO_ML. The dry bias in the model over central India using MIT and GO_ML may be due to the lower LHF observed over the region. For the other schemes (KUO and GRELL) LHF is significantly lower as may be noticed in Figure 14 and could be the cause of the dry bias. 


\section{Summary}

This study discusses the relevant features of ISM, viz. heat low, Somali jet and southwesterly wind, subtropical westerly, tropical easterly jet, etc., through a sensitivity analysis of RegCM4 simulation using five convection schemes. The model shows a positive temperature bias in the simulation of surface temperature with the MIT, GO_ML and GL_MO schemes, and a cold bias using the KUO and GRELL schemes. The spatial distribution and magnitude of surface temperature is slightly better simulated with GL_MO compared to the other convection schemes. The seasonal mean circulation, as well as the change in strength of circulation in the contrasting monsoon years (2007 and 2009), are well simulated by the model with MIT. Seasonal and monthly mean rainfall are underestimated by the model with all convection schemes and show a wet bias in the foothills of the Himalayas and NEI. It is noticed that GO_ML shows better skill in simulating monsoon rainfall.

The results indicate that the best CCS option varies from parameter to parameter and no particular convection scheme shows better performance in simulating all parameters (temperature, winds and rainfall). As seen before, surface temperature and rainfall amount are well reproduced by the model with GL_MO and GO_ML, while low level and upper level circulation are better simulated with MIT only. A variation in model performance is also noticed when the simulation over different homogeneous zones is taken into consideration. It is observed that the performance of the model with MIT is slightly inferior to GL_MO and GO_ML but substantially superior to the remaining CCS in simulating surface temperature and rainfall. As mentioned earlier, higher (lower) surface temperature (rainfall) over central and NWI in the model simulation with MIT may be due to higher (lower) sensitivity heat flux (LHF) noticed over those regions. Therefore, as far as detection of a single CCS is concerned, MIT may be considered as the most suitable for simulating the ISM.

\section{Acknowledgments}

The authors would like to acknowledge the Indian Institute of Technology Kharagpur for providing the necessary facilities to conduct this research. The International Center for Theoretical Physics (ICTP) is gratefully acknowledged for providing the Reg-
CM4 model. The National Center for Atmospheric Research (NCAR), Climate Research Unit (CRU) and National Oceanic and Atmospheric Administration (NOAA) are duly acknowledged for providing various input and validation datasets. The Center for Development of Advanced Computing (CDAC), Pune is acknowledged for providing the required computing facility. The Indian Meteorological Department (IMD) is duly acknowledged for providing the monsoon reports for the three studied years. The authors would like to thank the anonymous reviewers for their constructive suggestions and valuable comments, which improved the manuscript significantly.

\section{References}

Alapaty K., S. Raman, R.V. Madala and U.C. Mohanty, 1994. Monsoon rainfall simulations with the Kuo and Betts-Miller schemes. Meteorol. Atmos. Phys. 53, 33-49. doi: 10.1007/BF01031903

Ali S., L. Dan, C. Fu and Y. Yang, 2015. Performance of convective parameterization schemes in Asia using RegCM: simulations in three typical regions for the period 1998-2002. Adv. Atmos. Sci. 32, 715-730.

doi: 10.1007/s00376-014-4158-4

Almazroui M., 2013. Simulation of present and future climate of Saudi Arabia using a regional climate model (PRECIS). Int. J. Climatol. 33, 2247-2259.

doi: 10.1002/joc.3721

Almazroui, M., Islam, M.N., Al-Khalaf, A.K. and Saeed, F., 2016. Best convective parameterization scheme within RegCM4 to downscale CMIP5 multi-model data for the CORDEX-MENA/Arab domain. Theor. Appl. Climatol. 124, 807-823. doi: 10.1007/s00704-015-1463-5

Anthes R.A., 1977. A cumulus parameterization scheme utilizing a one-dimensional cloud model. Mon. Weather. Rev. 105, 270-286. doi: 10.1175/1520-0493(1977)105<0270:ACPSUA $>2.0 . \mathrm{CO} ; 2$

Anthes R.A., Y.H. Kuo, E.Y. Hsie, S. Low-Nam and T.W. Bettge, 1989. Estimation of skill and uncertainty in regional numerical models. Q. J. Royal Meteorol. Soc. 115, 763-806. doi: 10.1002/qj.49711548803

Arakawa A. and W.H. Schubert, 1974. Interaction of a cumulus cloud ensemble with the large- scale environment, Part I. J. Atmos. Sci. 31, 674-701.

doi: 10.1175/1520-0469(1974)031<0674:IOAC$\mathrm{CE}>2.0 . \mathrm{CO} ; 2$ 
Betts A.K., 1993. The Betts-Miller scheme. The representation of cumulus convection in numerical models. Meteor. Monogr. No. 46. J. Am. Meteorol. Soc, 159164. doi: 10.1007/978-1-935704-13-3_9

Bhaskaran B., R.G. Jones, J.M. Murphy and M. Noguer, 1996. Simulations of the Indian summer monsoon using a nested regional climate model: domain size experiments. Clim. Dynam. 12, 573-587. doi: 10.1007/BF00216267

Bretherton C.S., J.R. McCaa and H. Grenier, 2004. A new parameterization for shallow cumulus convection and its application to marine subtropical cloud-topped boundary layers. Part I: Description and 1D results. Mon. Weather. Rev. 132, 864-882.

doi: 10.1175/1520-0493(2004)132<0864:ANPFSC $>2.0 . \mathrm{CO} ; 2$

Collins W.D., C.M. Bitz, M.L. Blackmon, G.B. Bonan, C.S. Bretherton, J.A. Carton, P. Chang, S.C. Doney, J.J. Hack, T.B. Henderson and J.T. Kiehl, 2006. The community climate system model version 3 (CCSM3). J. Climate 19, 2122-2143. doi: 10.1175/JCLI3761.1

Das S., U.C. Mohanty and O.P. Sharma, 1988. Study of Kuo-type cumulus parameterizations during different epochs of the Asian summer monsoon. Mon. Weather. Rev. 116, 715-729.

doi: $10.1175 / 1520-0493(1988) 116<0715$ :SOK$\mathrm{TCP}>2.0 . \mathrm{CO} ; 2$

Das S., A.K. Mitra, G.R. Iyengar and S. Mohandas, 2001. Comprehensive test of different cumulus parameterization schemes for the simulation of the Indian summer monsoon. Meteorol. Atmos. Phys. 75, 227-244. doi: 10.1007/s703-001-8176-1

Das S., A.K. Mitra, G.R. Iyengar and J. Singh, 2002. Skill of medium-range forecasts over the Indian monsoon region using different parameterizations of deep convection. Weather Forecast. 17, 1194-1210. doi: 10.1175/1520-0434(2002)017<1194:SOMR$\mathrm{FO}>2.0 . \mathrm{CO} ; 2$

Dash S.K., M.S. Shekhar and G.P. Singh, 2006. Simulation of Indian summer monsoon circulation and rainfall using RegCM3. Theor. Appl. Climatol. 56, 161-172. doi: 10.1007/s00704-006-0204-1

Dickinson R.E., P.J. Kennedy and A. Henderson-Sellers, 1993. Biosphere-atmosphere transfer scheme (BATS) version 1e as coupled to the NCAR community climate model. National Center for Atmospheric Research, Climate and Global Dynamics Division.

doi: 10.5065/D67W6959
Emanuel K.A., 1991. A scheme for representing cumulus convection in large-scale models. J. Atmos. Sci. 48, 2313-2329.

doi: 10.1175/1520-0469(1991)048<2313:ASFRC$\mathrm{C}>2.0 . \mathrm{CO} ; 2$

Emanuel K.A. and M. Zivkovic-Rothman, 1999. Development and evaluation of a convection scheme for use in climate models. J. Atmos. Sci. 56, 1766-1782. doi: 10.1175/1520-0469(1999)056<1766:DAEO$\mathrm{AC}>2.0 . \mathrm{CO} ; 2$

Fritsch J.M. and C.F. Chappell, 1980. Numerical prediction of convectively driven mesoscale pressure systems. Part II. Mesoscale model. J. Atmos. Sci. 37, 1734-1762. doi: 10.1175/1520-0469(1980)037<1734:NPOCD$\mathrm{M}>2.0 . \mathrm{CO} ; 2$

Ghosh S.K., M.C. Pant and B.N. Dewan, 1978. Influence of the Arabian Sea on the Indian summer monsoon. Tellus 30, 117-125. doi: 10.1111/j.2153-3490.1978.tb00825.x

Giorgi F., N. Elguindi, S. Cozzini and G. Giuliani, 2011. Regional climatic model RegCM user's guide version 4.2. ITCP, Trieste, Italy.

Giorgi F., E. Coppola, F. Solmon, L. Mariotti, M.B. Sylla, X. Bi, N. Elguindi, G.T. Diro, V. Nair, G. Giuliani and U.U. Turuncoglu, 2012. RegCM4: Model description and preliminary tests over multiple CORDEX domains. Clim. Res. 52, 7-29.

doi: $10.3354 / \mathrm{cr} 01018$

Goswami B.N., D. Sengupta and G.S. Kumar, 1998. Intraseasonal oscillations and interannual variability of surface winds over the Indian monsoon region. J. Earth. Syst. Sci.107, 45-64. doi: 10.1007/BF02842260

Grell G.A., 1993. Prognostic evaluation of assumptions used by cumulus parameterizations. Mon. Weather. Rev. 121, 764-787. doi: 10.1175/1520-0493(1993)121<0764:PEOAU$\mathrm{B}>2.0 . \mathrm{CO} ; 2$

Grell G.A., Dudhia, J. and Stauffer, D.R., 1994. A description of the fifth-generation Penn State/NCAR mesoscale model (MM5). NCAR/TN-398 + STR NCAR technical note. doi: 10.5065/D60Z716B

Harris I., P.D. Jones, T.J. Osborn and D.H. Lister, 2014. Updated high-resolution grids of monthly climatic observations-the CRU TS3. 10 Dataset. Int. J. Climatol. 34, 623-642. doi: 10.1002/joc.3711

Holtslag A.A.M., E.I.F. De Bruijn and H.L. Pan, 1990. A high resolution air mass transformation model for 
short-range weather forecasting. Mon. Weather. Rev. $118,1561-1575$.

doi: 10.1175/1520-0493(1990)118<1561:AH-

RAMT $>2.0 . \mathrm{CO} ; 2$

Islam M.N., 2009. Rainfall and temperature scenario for Bangladesh. The Open Atmospheric Science Journal 3, 93-103.

doi: $10.2174 / 1874282300903010093$

Kain J.S., 1993. Convective parametrization for mesoscale models: The Kain-Fritsch scheme. Meteor. Mon. 46, 165-170.

doi: 10.1007/978-1-935704-13-3_16

Kalnay E., M. Kanamitsu, R. Kistler, W. Collins, D. Deaven, L. Gandin, M. Iredell, S. Saha, G. White, J. Woollen and Y. Zhu, 1996. The NCEP/NCAR 40-year reanalysis project. B. Am. Meteorol. Soc. 77, 437-471. doi: 10.1175/1520-0477(1996)077<0437:TNYRP>2.0. $\mathrm{CO} ; 2$

Kang I.S., K. Jin, B. Wang, K.M. Lau, J. Shukla, V. Krishnamurthy, S. Schubert, D. Wailser, W. Stern, A. Kitoh and G. Meehl, 2002. Intercomparison of the climatological variations of Asian summer monsoon precipitation simulated by 10 GCMs. Climate Dynamics 19, 383-395. doi: 10.1007/s00382-002-0245-9

Kang S., E.S. Im and J.B. Ahn, 2014. The impact of two land-surface schemes on the characteristics of summer precipitation over East Asia from the RegCM4 simulations. Int. J. Climatol. 34, 3986-3997.

doi: $10.1002 /$ joc. 3998

Kiehl J.T., J.J. Hack, G.B. Bonan, B.A. Boville and B.P. Briegleb, 1996. Description of the NCAR Community Climate Model (CCM3). Technical Note No. PB-97-131528/XAB; NCAR/TN--420-STR. National Center for Atmospheric Research, Climate and Global Dynamics Division, Boulder, CO.

doi: 10.5065/D6FF3Q99

Kuo H.L., 1965. On formation and intensification of tropical cyclones through latent heat release by cumulus convection. J. Atmos. Sci. 22, 40-63.

doi: 10.1175/1520-0469(1965)022<0040:OFAIOT $>2.0$. $\mathrm{CO} ; 2$

Kuo H.L., 1974. Further studies of the parameterization of the influence of cumulus convection on large-scale flow. J. Atmos. Sci. 31, 1232-1240.

doi: $10.1175 / 1520-0469(1974) 031<1232$ :FSOT$\mathrm{PO}>2.0 . \mathrm{CO} ; 2$

Lal M., G.A. Meehl and J.M. Arblaster, 2000. Simulation of Indian summer monsoon rainfall and its intrasea- sonal variability in the NCAR climate system model. Reg. Environ. Change 1, 163-179.

doi: $10.1007 / \mathrm{s} 101130000017$

Maity S., A.N.V. Satyanarayana, M. Mandal and S. Nayak, 2017. Performance evaluation of land surface models and cumulus convection schemes in the simulation of Indian summer monsoon using a regional climate model. Atmos. Res. 197, 21-41.

doi: 10.1016/j.atmosres.2017.06.023

Martínez-Castro D., R. Porfirio da Rocha, A. Bezanilla-Morlot, L. Alvarez-Escudero, J.P. Reyes- Fernández, Y. Silva-Vidal and R.W. Arritt, 2006. Sensitivity studies of the RegCM3 simulation of summer precipitation, temperature and local wind field in the Caribbean Region. Theor. Appl. Climatol. 86, 5-22.

doi: 10.1007/s00704-005-0201-9

Mohanty U.C., R. Bhatla, P.V.S. Raju, O.P. Madan and A. Sarkar, 2002. Meteorological fields variability over the Indian seas in pre and summer monsoon months during extreme monsoon seasons. J. Earth. Syst. Sci.111, 365-378. doi: 10.1007/BF02701981

Mohanty U.C., P.V.S. Raju and R. Bhatla, 2005. A study on climatological features of the Asian summer monsoon: dynamics, energetics and variability. Pure Appl. Geophys. 162, 1511-1541.

doi: 10.1007/s00024-005-2681-z

Nayak S., M. Mandal and S. Maity, 2017. Customization of regional climate model (RegCM4) over Indian region. Theor. Appl. Climatol. 127, 153-168. doi: 10.1007/s00704-015-1630-8

Oleson K.W., G.Y. Niu, Z.L. Yang, D.M. Lawrence, P.E. Thornton, P.J. Lawrence, R. Stöckli, R.E. Dickinson, G.B. Bonan, S. Levis and A. Dai, 2008. Improvements to the Community Land Model and their impact on the hydrological cycle. J. Geophys. Res.- Biogeo. 113. doi: 10.1029/2007JG000563

Pal J.S., E.A. Eltahir and E.E. Small, 2000. Simulation of regional-scale water and energy budgets: Representation of subgrid cloud and precipitation processes within RegCM. J. Geophys. Res. 105, 29579-29594. doi: 10.1029/2000JD900415

Pal J.S., F. Giorgi, Bi, X., N. Elguindi, F. Solmon, S.A. Rauscher, X. Gao, R. Francisco, Zakey, A., J. Winter and M. Ashfaq, 2007. Regional climate modeling for the developing world: the ICTP RegCM3 and RegCNET. Bull. Am. Meteorol. Soc. 88, 1395-1409. doi: 10.1175/BAMS-88-9-1395 
Parthasarathy B., A.A. Munot and D.R. Kothawale, 1994. All-India monthly and seasonal rainfall series: 18711993. Theor. Appl. Climatol. 49, 217-224. doi: 10.1007/BF00867461

Raju P.V.S., U.C. Mohanty and H.H. Hsu, 2010. A study on drought features of the Indian summer monsoon 2002. Meteorol. Atmos. Phys. 108, 43-55. doi: 10.1007/s00703-010-0082-z

Rao D.V.B., K. Ashok and T. Yamagata, 2004. A numerical simulation study of the Indian summer monsoon of 1994 using NCAR MM5. Journal of the Meteorological Society of Japan. Ser. II 82, 1755-1775. doi: $10.2151 /$ jmsj. 82.1755

Ratnam J.V. and K.K. Kumar, 2005. Sensitivity of the simulated monsoons of 1987 and 1988 to convective parameterization schemes in MM5. J. Climate 18, 2724-2743. doi: 10.1175/JCLI3390.1

Singh A.P., U.C. Mohanty, P. Sinha and M. Mandal, 2007. Influence of different land-surface processes on Indian summer monsoon circulation. Natural Hazards 42, 423-438. doi: 10.1007/s11069-006-9079-9

Shukla J. and D.A. Paolino, 1983. The Southern Oscillation and long-range forecasting of the summer monsoon rainfall over India. Mon. Weather. Rev. 111, 1830-1837.

doi: 10.1175/1520-0493(1983)111<1830:TSOAL$\mathrm{R}>2.0 . \mathrm{CO} ; 2$

Shukla J. and M.J. Fennessy, 1994. Simulation and predictability of monsoons. In: Procedures of the International Conference on Monsoon Variability and Prediction. Technical Report WCRP-84, World Climate Research Programme, Geneva, Switzerland, 567-575.

Sinha P., U.C. Mohanty, S.C. Kar, S.K. Dash and S. Kumari, 2013. Sensitivity of the GCM driven summer monsoon simulations to cumulus parameterization schemes in nested RegCM3. Theor. Appl. Climatol. 112, 285-306.

doi: 10.1007/s00704-012-0728-5

Steiner A.L., J.S. Pal, F. Giorgi, R.E. Dickinson and W.L. Chameides, 2005. The coupling of the Common Land Model (CLM0) to a regional climate model (RegCM). Theor. Appl. Climatol. 82, 225-243. doi: 10.1007/s00704-005-0132-5

Steiner A.L., J.S. Pal, S.A. Rauscher, J.L. Bell, N.S. Diffenbaugh, A. Boone, L.C. Sloan and F. Giorgi, 2009. Land surface coupling in regional climate simulations of the West African monsoon. Clim. Dynam.33, 869892. doi: 10.1007/s00382-009-0543-6
Tawfik A.B. and A.L. Steiner, 2011. The role of soil ice in land-atmosphere coupling over the United States: A soil moisture-precipitation winter feedback mechanism. J. Geophys. Res.- Atmos. 116.

doi: 10.1029/2010JD014333

Taylor K.E., 2001. Summarizing multiple aspects of model performance in a single diagram. J. Geophys. Res.Atmos. 106, 7183-7192.

doi: 10.1029/2000JD900719

Tchotchou L.D. and F.M. Kamga, 2010. Sensitivity of the simulated African monsoon of summers 1993 and 1999 to convective parameterization schemes in RegCM3. Theor. Appl. Climatol. 100, 207-220.

doi: 10.1007/s00704-009-0181-2

Tiwari P.R., S.C. Kar, U.C. Mohanty, S. Dey, P. Sinha, P.V.S. Raju and M.S. Shekhar, 2015. The role of land surface schemes in the regional climate model (RegCM) for seasonal scale simulations over Western Himalaya. Atmósfera 28, 129-142.

doi: 10.1016/S0187-6236(15)30005-9

Trenberth K.E., A. Dai, G. Van Der Schrier, P.D. Jones, J. Barichivich, K.R. Briffa and J. Sheffield, 2014. Global warming and changes in drought. Nat. Clim. Change 4, 17-22. doi: $10.1038 /$ nclimate 2067

Venkata Ratnam J. and E.A. Cox, 2006. Simulation of monsoon depressions using MM5: sensitivity to cumulus parameterization schemes. Meteorol. Atmos. Phys. 93, 53-78. doi: 10.1007/s00703-005-0160-9

Wang Y., O.L. Sen and B. Wang, 2003. A highly resolved regional climate model (IPRC- RegCM) and its simulation of the 1998 severe precipitation event over China. Part I: Model description and verification of simulation. J. Climate 16, 1721-1738.

doi: 10.1175/1520-0442(2003)016<1721:AHRRC$\mathrm{M}>2.0 . \mathrm{CO} ; 2$

Webster P.J., V.O. Magaña, T.N. Palmer, J. Shukla, R.A. Tomas, M.U. Yanai and T. Yasunari, 1998. Monsoons: Processes, predictability, and the prospects for prediction. J. Geophys. Res.-Oceans 103, 14451-14510. doi: 10.1029/97JC02719

Zeng X., M. Zhao and R.E. Dickinson, 1998. Intercomparison of bulk aerodynamic algorithms for the computation of sea surface fluxes using TOGA COARE and TAO data. J. Climate 11, 2628-2644. doi: 10.1175/1520-0442(1998)011<2628:IOBAAF>2.0. $\mathrm{CO} ; 2$ 
Zhong Z., 2006. A possible cause of a regional climate model's failure in simulating the East Asian summer monsoon. Geophys. Res. Lett. 33. doi: 10.1029/2006GL027654

Zhou T.J. and Z. Li, 2002. Simulation of the East Asian summer monsoon using a variable resolution atmospheric GCM. Clim. Dynam. 19, 167-180. doi: $10.1007 / \mathrm{s} 00382-001-0214-8$

Zhu P., 2015. On the mass-flux representation of vertical transport in moist convection. J. Atmos. Sci. 72, 44454468. doi: 10.1175/JAS-D-14-0332.1
Zou L. and T. Zhou, 2013. Improve the simulation of western North Pacific summer monsoon in RegCM3 by suppressing convection. Meteorol. Atmos. Phys. 121, 29-38. doi: 10.1007/s00703-013-0255-7

Zou L., Y. Qian, T. Zhou and B. Yang, 2014. Parameter tuning and calibration of RegCM3 with MIT-Emanuel cumulus parameterization scheme over CORDEX East Asia domain. J. Climate 27, 7687-7701. doi: 10.1175/JCLI-D-14-00229.1 